NBER WORKING PAPER SERIES

\title{
THE CURRENCY COMPOSITION OF INTERNATIONAL RESERVES, DEMAND FOR INTERNATIONAL RESERVES, AND GLOBAL SAFE ASSETS
}

\author{
Joshua Aizenman \\ Yin-Wong Cheung \\ Xingwang Qian \\ Working Paper 25934 \\ http://www.nber.org/papers/w25934 \\ NATIONAL BUREAU OF ECONOMIC RESEARCH \\ 1050 Massachusetts Avenue \\ Cambridge, MA 02138 \\ June 2019
}

We would to like thank Shi He, Roger Lee, and Tianyu Wang for research assistance. Useful comments of Michael Hutchison, Paul Luk, Kishen Rajan, Frank Westermann, Matthew Yiu, and the participants at the Conference on Global Safe Assets, International Reserves, and Capital Flow, May 20-21, 2019, Hong Kong are gratefully acknowledged. Of course, we are responsible for any remaining deficiencies or errors. The work described in this paper was partially supported by a grant from the Research Grants Council of the Hong Kong Special Administrative Region, China (Project \#: CityU 11500617). Aizenman gratefully acknowledges the financial support of the Dockson Chair at the University of Southern California. Cheung gratefully acknowledges the Hung Hing Ying and Leung Hau Ling Charitable Foundation (孔慶熒及梁巧玲慈善基金) for its support through the Hung Hing Ying Chair Professorship of International Economics (孔慶熒講 座教授(國際經濟)). The views expressed herein are those of the authors and do not necessarily reflect the views of the National Bureau of Economic Research.

NBER working papers are circulated for discussion and comment purposes. They have not been peer-reviewed or been subject to the review by the NBER Board of Directors that accompanies official NBER publications.

(C) 2019 by Joshua Aizenman, Yin-Wong Cheung, and Xingwang Qian. All rights reserved. Short sections of text, not to exceed two paragraphs, may be quoted without explicit permission provided that full credit, including $(\odot)$ notice, is given to the source. 
The Currency Composition of International Reserves, Demand for International Reserves, and Global Safe Assets

Joshua Aizenman, Yin-Wong Cheung, and Xingwang Qian

NBER Working Paper No. 25934

June 2019

JEL No. F15,F3,F31

\section{ABSTRACT}

This paper examines determinants of the international reserves (IR) currency composition before and after the Global Financial Crisis (GFC). Applying the annual data of 58 countries, we confirm that countries that trade more with the US, euro zone, UK, and Japan, and issue more debt denominated in the big four currencies (US dollar, euro, pound, yen) hoard more IR in these currencies. We find scale effects in which countries tend to diversify from the big four currencies as they increase their IR/GDP and that a growing shortage of global safe assets (GSAs) induces countries to hold more big four currencies. Countries hold less big four currencies as IR after the 2008 GFC, while they hold more of such currencies since the tapering of the Fed's quantitative easing. The 2008 GFC and QE tapering weakened and sometimes reversed the effect of several economic factors. We also find that TARGET2 balances matter for the currency composition in the euro zone; commodity-exporting countries tend to diversify their IR from the big four currencies when their terms of trade improve; and that the valuation effects induced by Euro/USD exchange rate changes diminish the significance of the GFC in explaining the currency composition of IR.

Joshua Aizenman

Economics and SIR

USC

University Park

Los Angeles, CA 90089-0043

and NBER

aizenman@usc.edu

Yin-Wong Cheung

Department of Economics and Finance

City University of Hong Kong

Hong Kong

yicheung@cityu.edu.hk
Xingwang Qian

Economics and Finance Department

SUNY Buffalo State

1300 Elmwood Ave

Buffalo, NY 14222

qianx@buffalostate.edu 


\section{The currency composition of international reserves, the demand for international reserves, and global safe assets}

\section{Introduction and overview}

The Global Financial Crisis [GFC] and its aftermath focused attention on central banks' and countries' balance-sheet exposure in a fragile world. A possible interpretation of financial instability involves the presence of multiple equilibria associated with leverage. Financial fragility may reflect concerns regarding the commitment and fiscal viability of policies needed to prevent a run on the banking system in the presence of balance-sheet exposures. ${ }^{1}$ In these circumstances, a country's central banks tend to hold more international reserves (IR) denominated in a key reserve foreign country if its households and private and public sectors borrow more debt denominated in the key reserve currency, or when it imports more goods and services produced by the key reserve country. Henceforth, we refer to this interpretation as the balance-sheet insurance hypothesis.

This hypothesis supplements earlier rationales for hoarding and using IR. Heller and Knight (1978) noted that central banks' currency composition matters in providing temporary import financing. Dooley et al. (1989) and Eichengreen and Mathieson (2000) focused on foreign exchange innervations, possibly dealing with accommodating exchange market pressures associated with financial outflows of debt and other financial assets. The balance-sheet insurance hypothesis also points to the role of IR currency composition in stabilizing the financial market by hedging the risk of currency mismatch (Schneider and Tornell, 2004). Aizenman and Lee (2007) interpreted the takeoff of precautionary IR hoarding by emerging markets in the 1990s as a response to the growing exposure to financial fragility and sudden stop crises (Calvo, 1998). This fragility was induced by the rise of financial openness of emerging markets, as well as

\footnotetext{
${ }^{1}$ Bocola and Lorenzoni (2017) provide an insightful model illustrating and explaining these issues in the context of Emerging Markets characterized by limited credibility of their fiscal backstop mechanisms. Domestic authorities can eliminate the crisis equilibrium by acting as a lender of last resort, but these interventions only work if they are fiscally credible. Foreign currency reserves holding hedge the government's fiscal position and enhance its credibility, thus improving financial stability. According to this interpretation, the "state of fundamentals" (like fiscal space, growth rates, etc.) determines the existence and multiplicity of equilibria. If the fundamentals are very strong, the private sector does not have the incentive to "run on the system," and the regime is stable. If the fundamentals are very weak, the private sector attacks the system, and the regime collapses. In between the very strong and the weak equilibria, a range of multiple equilibria exist. Earlier examples of such systems include Diamond and Dybvig (1983) and Obstfeld (1996).
} 
developing economies (EMDEs) embracing greater financial liberalization after the 1980s external debt crises.

The insurance and defensive role of IR during a financial crisis also points to the association between global safe assets (GSAs) and the IR currency composition. Central banks sell foreign exchange reserves to prop up the falling value of domestic currencies during financial crises and to stabilize the foreign exchange market (Dominguez et al., 2012). Amidst a financial crisis, investors may experience heightened risk aversion, inducing flight to safe haven assets, even at a cost of domestic assets' fire sales. ${ }^{2}$ Holding a certain portion of IR in the currencies of GSA countries allows central banks to defend flight-to-quality more effectively and at a lower cost. Caballero (2006) and Caballero et al. (2017) interpreted the GSA shortage conundrum as the outcome of higher demand for GSAs by EMDEs, highlighting the association between GSAs and the IR currency composition.

This paper aims at explaining the changing currency composition of IR in recent decades, controlling for pertinent financial and real variables as identified by the literature, as well as new factors that have emerged during and after the GFC. Such factors include access to elastic swap lines offered by the US FED and other key-currency countries; heightened demand for GSAs at times of global fragility; and the growing role of sovereign wealth funds (SWFs).

Due to a lack of detailed data on countries' actual currency composition, we use the aggregate share of IR of the currencies whose share of global IR exceeded 4\% in 2018: the US dollar, the euro, the yen, and the British pound, whose respective shares were $62.5 \%, 20.4 \%$, 4.8\% and 4.7\%. ${ }^{3}$ We call these four currencies the "big four" currencies, and the US, Euro area, Japan and Britain the big four countries. ${ }^{4}$ These data are from the IMF International Reserves and Foreign Currency Liquidity [IRFCL], which is composed of 58 countries, annual data, from 2000 to $2017 .^{5}$

\footnotetext{
${ }^{2}$ Obstfeld et al. (2010) describe the twin drains of sudden stops in external capital flows and internal drain from domestic M2.

${ }^{3}$ Not surprisingly, these four currencies are also the most heavily traded currencies in the global foreign exchange market (Bank for International Settlements, 2016).

${ }^{4}$ The aggregate share in the Chinese renminbi, despite its growing role in the international monetary system, is not included in our exercise. The IR share of the Chinese renminbi have increased from a low base to reach $1.4 \%$ by the first quarter of 2018. The data on China's share of allocated currency reserves are only partially available in the last few years.

${ }^{5}$ See Reuters, July 1, 2018, Richard Leong's report on the Foreign Exchange Analysis. Appendix B provides country names in data sample.
} 
Our study reveals complex, heterogeneous, and evolving patterns. The balance-sheet insurance motive applies to emerging markets and developing economies [EMDEs], but less so to advanced countries [ADVs]. Specifically, EMDEs that trade more with the big four countries and issue more debts denominated in their currencies tend to hold more IR denominated in the big four currencies. In contrast, IR holdings of the big four currencies decline in countries with higher (SWFs and the gold share relative to the official IR. Holding higher levels of IR/GDP encourages EMDEs to diversify their IR to currencies other than the big four. Euro countries, mostly ADVs, seem to behave differently from EMDEs - the more a euro country holds IR, the more it concentrates its IR into the big four currencies. An euro country tends to hold higher big four currencies of IR stock when it has more TARGET2 liability balance.

Lower availability of GSAs, as defined by the debt instruments of the big four countries, leads EMDEs to hold more IR in big four currencies. This finding holds using different measurement for GSAs, including treating TARGET2 payment balance as part of GSAs. The terms of trade (ToT) changes of commodity-exporter countries have a sizable impact on their IR currency composition — their IR diversification increases with stronger ToT and higher IR/GDP. We also find that the presence of SWFs significantly affects IR currency composition-an advanced country with a large SWF tends to diversify the IR currency composition from big four currencies, whereas an EMDEs' SWF does not impact the share of IR in big four currencies. ${ }^{6}$

The GFC was a watershed for the IR share of big four currencies. This share hovered around 98\% until 2008, dropping to about 92\% at the end of our sample (Figure 1). As these shift patterns coincide with the global financial cycle (Rey, 2015), we also study how the currency composition evolves over different phases of the financial cycle (Miranda-Agrippino and Rey, 2019). Specifically, we evaluate the impact of the Fed's quantitative easing (QE), changes in the market's risk tolerance, monetary tightening and interest rate tapering, and policies associated with the euro crisis.

\footnotetext{
${ }^{6}$ SWFs are by now major global players, with combined valuation was about 8 trillion US\$ at the end of 2018. The formation of SWF signals the wish to opt for greater divarication of the assets controlled by the public sector, impacting thereby the demand for international reserves (Aizenman and Glick, 2009). As of 2019, Q1, the Norwegian SWF, the largest and the most transparent fund reported that $28 \%$ of its assets were invested in fixed assets, and that US Treasuries accounted for $22 \%$ of its fixed-income investments. These developments imply that SWFs are a major player impacting the demand for GSAs, and indirectly the IR diversification pattern. The limited information about the asset composition of SWFs does not allow us to control fully for their global impact. Instead, we control for the sizes, subject to the available information.
} 
Indeed, we identified a regime shift after 2008 and after the Fed's interest rate tapering in both EMDEs and ADVs. The share of IR denominated in the big four currencies is lower after the 2008 financial crisis, but higher after the Fed's tapering. The balance-sheet motive still exists in EMDE after the 2008 financial crisis, but it is less prominent. The effect of IR/GDP on IR currency composition reversed its sign after the 2008 crisis - a higher level of IR/GDP is associated with a lower level of big four currencies in the IR held in EMDEs before the crisis, but with a higher level of big four currencies after $2008 .^{7}$

These effects do not occur in ADVs. ADVs diversify from the big four currencies by holding more gold as non-big four reserves before 2008. The 2008 financial crisis does not alter the effect of IR/GDP on the currency composition of IR in ADVs' economies. This result is in line with the view that elastic swap lines offered by the US FED to key OECD countries during the GFC provided credible reassuring signals, stabilizing these economies without the need to adjust their IR hoarding strategy. The effect of GSAs on IR currency composition does not change after 2008. In contrast, the Fed's QE tapers, signaling a future drop in GSAs availability that leads both EMDEs and ADVs to rush for more holding of big four currencies in 2014.

Observing the switch from a relatively weak US dollar in 2000-2007 to the strong dollar after 2008 GFC, we investigate the valuation effect that might influence the IR currency composition (Eichengreen et al, 2016). Under some bold assumptions induced by the lack of country specific data, the significance of the GFC diminishes once that we control for the valuation effects induced by Euro/US dollar exchange rate changes.

We start by analyzing canonical determinants of the currency composition of international reserves, including trade with the big four countries (Trade with Bigfour), anchors to reserve currencies, and the exchange rate regime. ${ }^{8}$ Next, we add the outstanding debt that a country issued and denominated in the big four currencies (Debt in USDEuro), and access to SWAP lines. Data availability enables us to cover 58 countries in our sample, of which 23 are

\footnotetext{
${ }^{7}$ While the drop of the big four currencies may be viewed as small in the context of the global crisis [from 98\% to about 92\%], our analysis shows that the volatility associated with the GFC induces significant results regarding the factors accounting the trends of IR diversification in the context of shocks impacting the supply and demand for GSA.

${ }^{8}$ Our analysis is inspired and updates studies that include Frenkel (1974); Heller and Knight (1978); Dooley et al. (1989); Eichengreen and Mathieson (2000); and Chinn and Frankel (2008).
} 
ADVs and 35 are EMDEs. We test and confirm time-varying and heterogeneous patterns across these groups, confirming and extending the earlier literature. ${ }^{9}$

We then test the possibility that central banks tend to diversify the currency composition of IR when the level of IR/GDP becomes high. We also explore the possible effects of GSAs. In principle, a GSA is any debt issued or guaranteed by a "safe” government, implying a country with its own central bank, stable currency, and effective protection of property rights (He et al., 2016a; 2016b). In practice, GSAs are usually safe and liquid assets, denominated in the currency of major advanced countries-particularly in US dollars and the debt of the euro's core. During financial turbulence that depletes the supply of GSAs, countries may have to beef up their holding of reserves in the big four currencies that have a high level of liquidity. Thus, the availability of GSAs and the demand for GSAs are likely to impact a country's IR currency composition. Finally, we investigate the regime-shifting role of the 2008 GFC and the Fed's QE tapering.

This paper relates to three strands of literature. First, it relates to the literature that identifies determinants of the IR currency composition (Dooley et al., 1989; Eichengreen and Mathieson, 2000; Chinn and Frankel, 2008). Previous papers have emphasized the ways the IR currency composition meets transaction needs (e.g., the payment to imports and external debt), as well as wealth diversification motives (Papaioannou et al., 2006). Our paper links IR currency composition to financial fragility and identifies balance-sheet insurance factors and GSAs that gained prominence after the GFC.

Second, a growing literature has studied the self-insurance role of IR in the world of sudden stops and financial crises (Aizenman and Lee, 2007; Cheung and Qian, 2009; Cheung et al., 2019; Obstfeld et al., 2010). Our paper deals with related issues through the lens of IR currency composition and illustrates how currency mismatches associated with international trade and external financial positions affect a central bank’s preferred currency composition of its IR.

Finally, a more recent literature stream has discussed the relation between central banks' reserves holding and GSAs. Accordingly, central banks' demand for liquid and safe assets may

\footnotetext{
${ }^{9}$ While the main purpose of EMDEs' holding IR is the precautionary motive and possibly mercantilism (Aizenman and Marion, 2003; Aizenman and Lee, 2007; Aizenman and Lee, 2008), ADVs may hold IR for foreign exchange intervention (Heller and Knight, 1978; Goldberg, Hull, and Stein, 2013).
} 
cause a shortage of GSAs (Bernanke et al., 2011; Caballero et al., 2017; Gourinchas and Jeanne, 2012). Conversely, the availability of GSAs, largely determined by a central country’s fiscal policy, may affect central banks' IR holdings in currencies of GSAs, a concern that we explore in the current paper.

The remainder of the paper is organized as the follows. Section 2 lays out the empirical model specification, explains the variables and interprets empirical results. In Section 3, we provide additional analyses. Section 4 concludes.

\section{Empirical Analysis}

\subsection{Basic specifications}

We start the study of currency composition by applying a linear dynamic panel-data regression:

(1) $Y_{i, t}=\alpha+\mu_{i}+\varphi * Y_{i, t-1}+\beta * X_{i, t-1}+\varepsilon_{i . t}$,

where $Y_{i, t}$ is the logit transformation of the share of big four currencies in the total IR held by country $i$ at time $t$ (Chinn and Frankel, 2008), and the lagged dependent variable, $Y_{i, t-1}$, is included to account for the persistence or inertia of holding of reserves over time. To account for possible biases induced by a lagged dependent variable in a fixed effect panel-data regression, we use the dynamic panel-data system GMM method to estimate the specification (Anderson and Hsiao, 1982; Arellano and Bond, 1991).

The vector, $X_{i, t-1}$, contains economic determinants; namely,

(a) the ratio of country i's trade (imports+exports) with the US, Euro area, Japan, and UK to its total trade with the rest of the world (Trd with bigfour);

(b) a dummy variable that assumes the value of one if country $i$ anchors its currency to either the US dollar, euro, pound, or yen (Anchor);

(c) an indicator variable (Xchg_rgm) that captures the exchange-rate regime arrangement of country $i$ from hard peg to freely floating (Ilzetzki, Reinhart, and Rogoff, 2016);

(d) the share of gold in the total IR holding of country $i$ (Gold Share),

(e) country i’s share of world GDP (GDP Share),

(f) an SWF variable given by the US dollar value of a country's SWF in log;

(g) the share of the stock market turnover volumes of the big four countries to the total global stock market turnover (Stock Mkt Size); and 
(h) the weighted average of inflation differentials between the big four countries and other OECD countries (Inflation Diff). The explanatory variables are lagged one year to mitigate endogeneity issues.

The trade and exchange-rate arrangement factors are canonical economic determinants. ${ }^{10}$ We expect a country to hold more IR in the currency of a country with which it trades more; if the country anchors to an international currency, it tends to hold more of that currency in its IR. The share of gold is introduced to account for possible motives when a country diversifies away from foreign currencies to a precious commodity with a long history of serving as international reserve-namely, gold. The country's share of world GDP controls for possible scale effects that may affect diversification patterns of large countries. The SWF variable is used to study the implications of SWFs for reserve-holding behaviors. The two "global" factors - namely the relative size of the stock markets ${ }^{11}$ and the relative inflation rate of the big four countries —are in line with the scaling conjecture of Chinn and Frankel (2008). In addition, a large financial market and positive inflation experiences tend to be valuable attributes of an international reserve currency.

Due to the differed motives of IR that are held by central banks in EMDEs and ADVs, the precautionary motive drives IR hoarding in EMDEs, while in ADVs, holding IR is mostly for foreign exchange interventions (Goldberg et al., 2013; Neely, 2000; Obstfeld, 1983;). Thereby, we expect EMDEs and ADVs to behave differently in the currency composition in their IR holdings. In Table 1, we report the results derived from the whole country sample, as well as the subsamples of EMDEs and ADVs. As expected, the share of the big four currencies exhibits inertia and path-dependency behavior. The inertia variable $\left(Y_{i, t-1}\right)$ is significant in both the full country sample and the two subsamples. The degree of persistence is much higher in the ADVs' subsample than the EMDEs - the former yields a coefficient estimate of 0.532 while the latter is 0.284. The large degree of persistence displayed by ADVs is likely attributed to the relatively high degree of homogeneity among such countries. ${ }^{12}$

\footnotetext{
${ }^{10}$ Frenkel (1974), Papaioannou et al. (2006), and Ito et al. (2015).

11 The potential role of bond markets is studied via the GSA variable in the subsequent subsections.

12 The higher macroeconomic volatility of EMDEs relative to the ADVs may be another contributing factor to EMDEs' lower persistence.
} 
Among the economic determinants, the Trade with bigfour variable is the only variable that is significant in both the full country sample and the EMDEs' and ADVs' subsamples. In these three cases, the trade variable yields the expected significant positive sign- the more a country trades with the big four countries, the more it holds their currencies in its reserves account. The group of EMDEs shows a stronger trade effect than the ADVs.

The “Anchor" variable has the expected positive coefficient-indicating that a country holds more of a currency that it is pegging to. However, it is only statistically significant for the full country sample and the EMDEs subsample (Beck and Rahbari, 2011), but not for the ADVs' samples. This may reflect the greater ability of ADVs' economies to borrow in their own currencies, a factor that reduces their exposure to sudden stop crises. Our results suggest that for ADVs, a significant and positive association exists between exchange rate flexibility and the share of big four currencies (Eichengreen et al., 2016). In countries that lean against the wind to mitigate exchange rate fluctuations, the greater liquidity of the big four foreign exchange market may increase their attractiveness for intervention operations.

The "Gold Share” is significant only for the EMDEs sample and has a positive sign, indicating that EMDEs, but not ADVs, tend to diversify in the big four reserve currencies. The GDP Share has different signs for the ADVs' and EMDEs' subsamples and is insignificant in the three cases under consideration.

While the SWF variable yields an expected negative sign in both the full sample and subsamples, it is only statistically significant in the full sample. That is, the presence of an SWF tends to lower the share of holdings in the big four reserve currencies. This finding is consistent with the argument by Ben-Basset (1984) who proposed to use a substitution account to diversify away from USD reserves and Papaioannou et al. (2006) who assessed diversification away from USD to euros with a mean-variance framework. The setup of an SWF signals that a country is willing to diversity and improve its national wealth management, where IR are usually invested in low-yield US treasury securities and other safe assets and incur substantial social costs (Rodrik, 2006). The insignificance in the subsamples can be due to a reduction in sample size when we moved from the full sample to the subsamples.

Of the two global factors, the relative size of the stock markets displays the expected positive sign—a large financial market is a contributing character of a reserve currency. The significance of the variable is probably supported by the reserve behavior of EMDEs, but not 
ADVs. The other global factor, the "Inflation Diff” variable, however, has differential effects for ADVs and EMDEs and is insignificant for these two subsamples and the full sample.

The over-identification Hansen J statistics (Hansen, 1982) and the serial correlation AR(1) and AR(2) statistics (Arellano and Bond,1991) presented near the bottom of Table 1 indicate that the estimated residuals of reported specifications are well behaved. Because our dependent variable is a logit-transformed variable, we employ the pseudo R2 estimate that is given by the squared correlation of predicted and actual values of the dependent variable to assess the performance of a fitted model (Cox and Wermuth, 1992; Everitt, 2002; Zheng and Agresti, 2000). The pseudo R2 estimates indicate that the model explains the EMDEs slightly better than the ADVs.

In sum, results in Table 1 show that the share of big four currencies to total reserves on average displays a considerable level of persistence and responds to the trade factor for both ADVs and EMDEs. Another main feature of these results is the differential behavior of ADVs and EMDEs. The variables “Anchor," "Gold Share,” and "Fin Mkt Size” are significant determinants for EMDEs, but not for ADVs. On the other hand, ADVs, but not EMDEs, respond significantly to "Xchg_rgm.” This finding echoes previous results on different reserve-hoarding behaviors of developed and developing countries ${ }^{13}$

\subsection{Currency denomination of debts and swap arrangements-the balance-sheet insurance consideration}

The endogenous interaction between debt denominated in local currency and foreign currencies in the possible presence of financial instability generates multiple equilibria in which a bad equilibrium is characterized by dollarization and financial instability (Bocola and Lorenzoni, 2017). The denominated debt of foreign currencies held by households, private firms, and public sectors is a source of financial instability in EMDEs. Such currency mismatch on EMDEs' balance sheet is exacerbated during financial turmoil when the domestic currency is under substantial devaluation pressure. According to Bocola and Lorenzoni (2017), the holding of foreign currency reserves enhances the government's fiscal credibility, and thus can eliminate the bad equilibrium. We label this role of IR as "balance sheet insurance." Following their argument, we test the balance-sheet insurance hypothesis by examining the association between

\footnotetext{
${ }^{13}$ See, for example, Aizenman et al. (2015), Bussière et al. (2015), and Cheung and Ito (2009).
} 
a country's IR currency composition and its foreign currency denominated debt. If there is a balance-sheet insurance motive, a country tends to hold more of a reserve currency in its IR when it issues more debt that is denominated in that particular reserve currency.

Table 2 presents the debt roles in the US dollar and the euro. ${ }^{14}$ Specifically, we consider the Debt in USDEuro variable, which is the share of total outstanding international debt securities that a country issues in US dollars and euros. In addition, we include the SWAP variable that indicates the presence (or absence) of a currency swap agreement with the Fed, the ECB, or the Bank of Japan. Obstfeld et al. (2009) and Aizenman et al. (2011) documented the reliance on central banks’ swap lines during the GFC, especially by developed countries, and suggest that such swap lines substitute for international reserves. To account for this substitution effect, we include an interaction term, Debt in USDEuro * SWAP, in the regression.

Column (1) reports the marginal effect of Debt in USDEuro in the presence of significant economic determinants identified in Table 1. The positive coefficient estimate is in line with the presumption that a country tends to hold more IR in big four currencies when it issues more debt securities that are denominated in the leading reserve currencies, US dollar, and euro. Inclusion of this debt variable improves the model performance - the pseudo R2 estimate is noticeably larger than that reported for the specification reported in Column 1 of Table 1 . The result lends support to the notion of the balance-sheet insurance effect. ${ }^{15}$

The marginal effect of swap arrangements is presented in Column (2). The SWAP variable yields a negative but insignificant coefficient estimate. Columns (3) and (4) report the combined effects of the debt and swap variables. The Debt in USDEuro shows a consistently significant positive effect, while the SWAP variable effect only comes through its interaction with the debt variable. Specifically, for a given debt level issued in the US dollar and the euro, the presence of a swap arrangement tends to lower the share of reserve holdings in the big four currencies. This result is in line with the view that access to elastic swap lines offered by the US FED and the central banks of other key currencies can affect a country’s IR hoarding behavior, as such swap lines provide credible fiscal signals that stabilize the economy without the need to adjust the country’s IR hoarding strategy.

\footnotetext{
${ }^{14}$ We do not have data on debt securities denominated in pounds or yen.

${ }^{15}$ We also considered the case of replacing "Trade with Bigfour" with "Import from Bigfour," which is given by the ratio of a country's imports from the US, EU, Japan, and UK to its total imports from the rest of the world. Nevertheless, the import-based variable offers a worse performance and thus is not discussed in the text.
} 
Tables (3) and Table (4) present the regression results from the EMDEs' and ADVs' subsamples, respectively. The balance-sheet insurance theory works better for EMDE countries than ADV countries. The marginal effect of the Debt in USDEuro is positive for the EMDEs (Table 3), but negative for ADVs (Table 4). The relative Debt in USDEuro result is in line with Goldberg, Hull, and Stein (2013) who showed that IR in ADVs are mainly used for foreign exchange market intervention and less for insurance purposes. On swap arrangements, both EMDEs and ADVs experience a negative effect, though for the former country group the effect is displayed via the interaction term, while the latter group is displayed via the SWAP variable directly. This may reflect the fact that the EMDEs' swap lines were more limited than the elastic access extended by the swap-lines offered to ADVs' economies during and after the GFC.

Results in Tables 3 and 4 reinforce the inference that the reserve-holding behaviors of EMDEs and ADVs are quite different. Further, the inclusion of the Debt in USDEuro and SWAP alters the significance of other economic determinants and, according to the pseudo R2 estimates, improves the specification performance of the ADVs better than that of EMDEs.

\subsection{Scale and global safe asset effects}

Will central banks diversify their holdings of IR away from the big four currencies when their holdings increase? To assess this possibility, we add the IR normalized by GDP as a control variable to the regression analysis, and a negative coefficient estimate is interpreted as an (indirect) evidence of diversification attributed to the scale effect.

In addition to the scale effect, this subsection also considers the implications of GSAs availability for the share of the big four currencies in holdings of reserves. We construct a GSA proxy variable that is given by the total consolidated central government debts (Maastricht definition) of Germany, Japan, the UK, and US, normalized by the world GDP. ${ }^{16}$ Recognizing the complexity of measuring GSAs (Caballero et al., 2017), we consider a few alternative proxies for GSAs.

Given the differential reserve-hoarding behaviors documented in previous subsections, we separately assess the subsamples of EMDEs and ADVs and find that both the normalized IR and GSA variables are insignificant in all the specifications considered for the ADVs'

16 Gourinchas and Jeanne (2012), for example, suggest that only public safe assets, if appropriately supported by monetary policy, provide sufficient insurance against global shocks. 
subsample. Thus, for brevity, we only discuss the scale and GSA effects of the subsample of EMDEs.

Table 5 shows that, either entered the regression individually or jointly, the normalized IR and GSA variables are statistically significant and improve the performance of the regression as indicated by the pseudo R2 estimates. The negative coefficient estimate of the normalized IR variable is in accordance with the diversification motive; the emerging market and developing economies, on average, tend to diversify away from the big four currencies when their levels of reserve holdings are high.

The negative GSA effect is in line with the view that a shortage of GSAs can shift the demand for international reserves toward the big four currencies. The result can be attributed to the complementary of GSAs and other assets denominated in the big four currencies. For instance, the market typically experiences an insufficient supply of GSAs during turbulent market conditions - a notable example is the recent GFC. Such conditions are also periods in which countries would like to have sufficient liquid reserves to fend off impacts of any adverse shocks. With the shortage of GSAs, countries opt for alternative assets denominated in the big four currencies. ${ }^{17}$

The estimation results from alternative GSA specifications are presented in Table 6. An alternative GSA variable is defined by the total OECD central government debts that are rated AA and normalized by the world GDP (Eichengreen et al., 2016). We label it as GSA_OECD. In addition to the quantity measure, we consider a price measure that is given by the average yield of a ten-year government bond of the US, Germany, the UK, and Japan, adjusted by the average yield of emerging market economies as represented by Korea, Mexico, Russia, and South Africa (Krishnamurthy and Vissing-Jorgensen, 2012). The proxy variable is labeled GSA_YD. We postulate that a small value of GSA_YD indicates a (relatively) high availability of safe assets. ${ }^{18}$

In Table 5, either GSA_OECD or GSA_YD qualitatively replicate the GSA effect. Specifically, GSA_OECD displays a positive effect and GSA_YD a negative effect in Table 6. The results suggest that the GSA effect is not purely driven by the choice of GSA measure.

17 Note that high levels of IR demand by EMDEs can drive up the demand for GSAs, which leads to a shortage of GSAs. Our use of lagged GSA variable should mitigate the endogeneity issue. We will discuss this issue further in the next section.

18 The results presented below are qualitatively the same when the proxy variable is adjusted for exchange rate variations against the USD. 
A decades-long shortage of GSA availability may tilt the financial system toward the issuance of "private label" pseudo-safe assets—for example, AAA-rated securitized instruments by the private financial industry. Safe assets are expected to preserve their value during adverse systemic events (Caballero and Farhi, 2017). However, the eruption of the 2008 financial crisis suddenly stripped the AAA safety status of such pseudo-safe assets, causing a sudden drop in the GSA supply. At the same time, the demand for GSAs surged due to the flight to safety during the financial crisis. Thus, the dynamic of the GSA demand-and-supply relation during crises periods is quite different than during tranquil times; as such, we expect the different effect of GSAs on the IR currency composition during turmoil vis-a-vis tranquil times. To investigate this possibility, we use the VIX index, the global financial fear factor, to indicate turmoil and tranquil financial situation - the VIX is higher when financial markets experience more turmoil. As shown in Column (3), a higher lagged VIX is associated with a lower share of big four currencies in IR, perhaps again reflecting a flight-to-quality situation during tumultuous times, and thus inducing a drop in the big four share of international reserves. This flight-to-quality argument is reinforced by the positive estimate of the interaction term, GSA * VIX.

\subsection{The regime-shift effect of the 2008 GFC}

Important financial events that potentially reshape the global financial landscape impose a regime-shift effect on the currency composition of IR. For example, Eichengreen et al. (2016) found that the breakdown of the Breton Woods system when most advanced countries switched from a fixed exchange rate to a floating rate caused a shift in determinants of the IR currency composition. To what extent was the evolution of the international reserves' share in the big four currency affected by the 2008 GFC?

Figure 1 shows an apparent change in the world's holding big four currencies as IR versus other reserve currencies around 2008 GFC — that is, less than 10 years after 2008, the share of big four dropped about 98\% to about 92\%. Using the EMDEs' and ADVs' samples that we are examining in this paper, we plot the average IR share in the big four currencies for both EMDEs and ADVs in Figures 2 and 3. Both figures indicate the watershed moment of the 2008 GFC in shifting IR currency composition, although ADVs seem to be impacted more.

To further assess the GFC implications, we include a GFC dummy variable (GFC08) and its interaction with other potential determinants in the regression exercise. Table 7 summarizes 
the results and presents the specifications with significant estimates for the EMDE and ADV subsamples. ${ }^{19}$

The specification of EMDEs is presented under the "EMDE" column in Table 7. As expected, we find a significant negative GFC08 coefficient estimate, which indicates a drop in the share of the big four currencies after the GFC. This may reflect the partial depletion of reserves due to flight-to-quality during the crisis, as well as the greater use of prudential regulations aimed at reducing hard-currency borrowing by EMDE, and capital inflows from key OECD countries searching for higher yields [Aizenman, Chinn, Ito (2017)].

Notice also that three economic factors' interaction term with GFC08 are estimated significantly and the signs are opposite to that of the corresponding stand-alone economic factor. These results suggest that the effects of these economic factors were either weakened or reversed after the 2008 GFC. First, the importance of trade with big four countries on the share of reserves allocated to big four currencies declined after the 2008 GFC. Second, larger-sized EMDEs (GDP Share) that diversify away from the big four reversed their behavior and accumulated big four currencies after the 2008 GFC. Finally, higher IR/GDP is found to be associated with a higher share of international reserves allocated to the big four currencies after the crisis, reversing the pattern before the GFC.

These changes may reflect a heightened sensitivity of EMDEs to volatile financial flows during and after the GFC. This volatility reflects mixed patterns — periods dominated by the search for yields following the decline in interest rates in the big four-induced inflows to EMDEs, and periods dominated by growing global uncertainty induced occasional outflows from EMDEs in search of a "safe haven." These post-GFC "regime switches" might explain the changes in the key parameters from the before-to-after GFC subsamples that we identified in the regression.

In the presence of the GFC08 effect, GSAs are not found to significantly affect the share of big four currencies in EMDEs' IR until the Fed's QE tapering. This is consistent with those in Tables 5 and 6 in which the shortage in GSA supply shifts EMDEs to a demand for more big four currencies.

\footnotetext{
${ }^{19}$ For consistency, we use Tables 3 and 4 as the standard specifications for EMDEs and ADVs sample regressions, respectively. Independent variables that are presented in Table 3 are presented in the "EMDE" column of Table 7; those in Table 4 are included in the "ADVs" column "ADVs".
} 
Similar to GFC08, the Fed's QE tapering (QE TAPER) caused a regime-switch effect on EMDEs' IR currency composition behavior. Contrasting this to that of GFC08, EMDEs hold more big four currencies in their international reserves after QE tapering and the regime-shift effect of QE tapering is five times higher than that of the 2008 GFC (e.g., 25 versus -5).

In the case of ADVs, we find the same regime-switch effect of both the 2008 GFC and the Fed's QE tapering, although both coefficients are smaller than those in the EMDEs' samples. The financial crisis and monetary shocks in the center country seem to insert a larger spillover effect on EMDEs than ADVs. After controlling for the significant and persistent GFC effect, the diversification effect of gold (Gold Share) is weakened.

The estimation of the same 2008 GFC effect and the Fed's QE tapering on the currency composition of IR for both EMDE and ADV countries suggests that the global financial cycle (Rey, 2015) plays an important role in determining IR currency composition. The 2008 GFC followed by a QE policy and subsequent QE tapering are essentially financial and monetary policy shocks, which, according to Miranda-Agrippino and Rey (2019), altered the global financial cycle, including the global co-movements of risky assets prices, capital flows, and credit growth. While the QE policy from the center country creates easy credit and capital flows to peripheral EMDEs in search of yield, QE tapering results in global money contraction and leads to deleveraging in global financial institutions, credit tightening, and strong retrenchments of international credit flows from EMDEs. Thus, both QE and QE tapering change the domestic and global financial environment as well as the risk perception of both private investors and central bank policy makers. These changes are eventually reflected in the change in IR currency characteristics that are designed to safeguard a country's systematic risk.

To recap, this section offers an updated empirical analysis of the currency composition of international reserves. In addition to the canonical determinants of IR currency composition, we account for balance-sheet insurance motives and find that such motives that apply in EMDEs but not in ADVs. If a country holds more IR, it tends to diversify from major reserves currencies. The shortage of GSAs induces EMDEs to hold more IR in the big four currencies. The 2008 global financial crisis and the Fed's QE tapering impose a significant regime switch, effecting and reshaping the currency composition of IR in both EMDEs and ADVs. These results suggest that the global cycle is an important determinant of IR currency composition. 


\section{Additional Analyses: Euro Countries, Commodity Countries, and Valuation Issues}

One of the observations made in the previous section is that shares of reserves in the big four currencies in EMDEs and ADVs display different patterns and dynamics. Such differences are likely attributable to distinct economic characteristics shared by these two groups of countries. In this section, we explore the reserve hoarding of two other groups of countriesnamely the group of euro countries and the group of commodity exporters.

\subsection{Euro area countries}

Currently, the euro is the officially currency of 19 EU member countries. Is the reserve behavior of this currency bloc different from other countries? Arguably, for the euro area countries, debts denominated in euros may not trigger the balance-sheet insurance motive of reserve hoarding the same way as non-euro countries. Further, open positions in the eurosystem's clearing system, called TARGET2, reflects net capital balances between euro countries that can affect their reserve-hoarding behavior. Table 8 presents results of considerations of these two factors. ${ }^{20}$

To capture the balance sheet effect for euro countries, we replaced Debt in USDEuro with Debt in USD — the share of total outstanding international debt securities issued in US dollars. For the TARGET2 balance effect, we consider the following three channels via which it can affect reserve-hoarding behaviour:

(1) One channel is the direct effect of TARGET2 balance on IR currency composition [TB2/GDP]. Since TARGET2 balance is a liability for the majority of euro countries, we expect a higher liability in euros leads a country to hold more IR in euros.

2) We assume the German TARGET2 balance ${ }^{21}$ is an alternative form of GSAs of other euro countries and add it to the GSA variable [GSA_T2], and

20 TARGET2 balances are akin to swap line arrangements implemented via the ECB, where creditor Eurozone countries (mostly Germany and other core countries) provide access to credit lines to the indebted countries (mostly to the Eurozone countries affected the most by the Euro crisis - Italy, Ireland, Greece, Portugal, and Spain). Similarly to swap lines, the provision of these lines is subject to the discretion of the ECB and the creditor countries. In 2012, at the peak of the Euro crisis, German's TARGET2 credit reached about 700 Billion euro, and the combined TARGET2 debit reached more than trillion euro. Uncertainties regarding the stability of the Eurozone triggered by the Euro crisis may be a factor constraining the viability and future functionality of TARGET2. See Steiner et al. (2019) and the references therein for further analysis.

$21 \quad$ Germany is the major TARGET2 system creditor that provides euros to "common pool" of the T2 payment system. Due to the special position of Germany in the TARGET2 system, we exclude it from our sample. 
3) We presume that TARGET2 liability has heightened risk implications when it crosses some thresholds. We use one standard deviation of TB2/GDP as the threshold and use the amount of T2B exceeding 1 s.d. threshold [T2B_threshold] as an independent variable. Additionally, we single out five euro-crisis-inflicted countries-Cyprus, Greece, Ireland, Portugal, and Spain — to examine whether they behave differently with the TARGET2 effect.

Table 8 shows the results are consistent in general with those in the previous section, finding the presence of the balance-sheet insurance motive, SWF diversification, strong inertia, and a significant GSA effect. An exception is that the scale effect appears to be reversed-in the euro zone, countries tend to hold more in big four currencies when they increase the IR hoarding level. ${ }^{22}$ As expected, higher-level TARGET2 liability is found to increase the share of big four in IR [Column (2)]. This is consistent with our balance-sheet insurance argument. Treating German TAREGET2 as an alternative GSA increases the supply of GSAs, possibly alleviating the GSA shortage effect on IR holding in the big four currencies. This expectation is confirmed in Column (3) in which the coefficient of GSA_T2 is slightly smaller than GSA in Column (1).

Column (4) shows whether a country's holding above a threshold of TARGET2 liability poses an insignificant effect on the country's currency composition structure in IR. Similarly, five euro-crisis-affected countries do not behave differently than others in the holding of big four currencies. Interestingly, it seems that these five countries reduce their share of big four currencies when their TARGET2 liability becomes higher; however, this estimate is insignificant.

In passing, we also consider cases of non-euro countries and non-euro EMDE countries. The empirical results are quite similar to those in Table 5; specifically, the Debt in USDEuro effect is positive and both IR/GDP and GSA effects are negative. ${ }^{23}$

\subsection{Commodity exporters}

Table 9 presents the results obtained for commodity-exporting countries. We consider a country is a commodity exporter if its exports of fuel, ores, and metals exceed $25 \%$ of its total

\footnotetext{
22 This result is true when all ADVs are included in the regression. The results from the sample of ADVs are available upon request.

23 These results are not presented for brevity, and are available upon request.
} 
merchandise exports. ${ }^{24}$ It is conceived that the commodity exporter's term of trade has nonnegligible implications for its economy and, hence its reserve-hoarding behavior; a case in point is the Russian experience (Aizenman and Sun, 2012). We include a terms of trade variable (ToT) that measures the term of trade improvement when its value is higher. When a country's ToT improves, it tends to hoard more IR, which induces the scale effect to diversify away from big four currencies in IR. To capture the interaction dynamic between ToT and IR/GDP level and their combined effect on the currency composition of IR in commodity exporters, we add an interaction term, IR/GDP * ToT, in the regression.

Results in Table 9 show that for these commodity exporters, ToT has a negative effect; that is, when ToT improves, commodity exporters are inclined to diversify their IR from big four currencies. Although the scale effect from IR/GDP exists in commodity exporters, the effect is stronger when compared to EMDE sample results in Table 5. Thus, both ToT and IR/GDP pose diversification effects on the share of big four currencies in commodity-exporting countries.

Besides the significant effect from both ToT and IR/GDP, their interaction term, IR/GDP * ToT, is estimated to be positive and significant. Since both ToT and IR/GDP are negative, a positive interaction term suggests that the diversification effect of ToT is reduced when the IR/GDP is high; or the effect of IR/GDP weakens if ToT improves in commodity-exporting countries.

In passing, we note that the ToT variables are not significant for the sample of all EMDEs.

\subsection{The valuation effect}

Due to the exchange rate changes among currencies held as IR, the IR currency composition could change even in the absence of active reserve management. This valuation effect is largely neglected in the literature, but recent IR studies ${ }^{25}$ have pointed out its importance. For instance, Eichengreen et al. (2016) showed that the fall of the sterling pound as a major reserve currency around the time of the collapse of the Bretton Woods System reflects the impact of the pound devaluation. Similarly, Frankel (2007) pointed out that the declining global share of US dollars after 1976 is partly due to the depreciation of USD. Indeed, as Figure

$24 \quad$ The list of commodity-exporting countries is given in Appendix B.

25 See for example, Dominguez et al. (2012) and Eichengreen et al. (2016). 
4 shows, a strong correlation exists between euro value (plot as the dash-line) and the global share of euros as reserve currency (red line). According to this data plot, one could argue for a plausible valuation effect, at least for the euro.

In this section, we assess the robustness of our results by taking the valuation effect into consideration. To account for the valuation effect due to the exchange rate change, ${ }^{26}$ we need to find a numeraire currency. As the IR currency composition data are accounted in USD, and the Euro and USD are two major reserve currencies, we choose to use the Euro as the numeraire currency and study the valuation effect caused by the changes in the euro/USD exchange rate. The IMF moving average exchange-rate approach is used to convert USD-denominated IR data into Euros counted IR data. ${ }^{27}$ Since we do not have country-specific data for the composition of each individual currency in the IR, we assume all countries hold the same currency composition as the world (IMF COFER data).

To save space, we opt to report Table 10 that replicates the regressions in Table 7, where we examine the impact of the 2008 GFC and the Fed's rate tapering on the currency composition of IR. Overall, the results are similar to those in Table 7, but with three important exceptions: (1) the impact of the 2008 GFC becomes insignificant, although it is still negative in EMDEs' sample; (2) the scale effect from the IR level (IR/GDP) is now insignificantly negative; and (3) the GSA effect becomes significantly positive before the Fed's interest rate tapering, but is reversed after tapering. The decline in the significance of the 2008 GFC dummy variable once we control for the euro/dollar rate probably reflects the fact that the 2008 GFC variable captures the switch from a relatively weak dollar during 2000-2007 to the strong dollar during 20082017. This market adjustment is in line with the dollar shortage triggered by the GFC and the "safe haven" and greater liquidity of the dollar market.

The lack of country-specific data implies that we have to interpret our results on the valuation effect with caution. In this subsection, we assume all countries possess the same IR currency composition as the world does; and we focus only on accounting for the euro/USD valuation. Undoubtedly, having more refined data may alter some of the results, allowing a sharper identification of the unique role of the dollar before and after the GFC.

26 The valuation effect could stem from either exchange rate fluctuation or the gain/loss from investments of IR assets (Dominguez et al, 2012). This paper considers only the exchange-rate valuation effect.

$27 \quad$ Wong (2007) provided technical details for the IMF moving average approach. 


\section{Concluding Remarks}

Our paper illustrates the dynamic changes modifying the demand for IR, the IR share of the big four currencies, and the varying importance of "safe assets" over time. In the context of the evolving literature, we recall that the 1997 East Asian Crisis was a watershed event explaining the reserve-hoarding takeoff observed in that part of the world, as well as in other emerging markets in the 1990s. The Global Financial Crisis validated the potential benefits of hoarding, but it also illustrated the need to supplement the hoarding of IR in "good times” with macro prudential regulation and other ways of buffering the economy in turbulent times. The crises brought to the fore the supplementary role of sovereign wealth funds, access to swap lines, Target2 credit arrangements, and the quest for "safer assets.” Our paper identifies these factors and explores their impact on the IR share on the big four currencies. Over time, we expect more changes to come, including a growing role of China in the global monetary system and credit arrangements, and experimentations with new policies and hedging mechanisms. 


\section{Reference:}

Aizenman, J., Cheung, Y-W., H., Ito 2015: International Reserves Before and After the Global Crisis: Is There No End to Hoarding? Journal of International Money and Finance 52 (April), 102-126.

Aizenman, J., Lee, J., 2007. International reserves: precautionary versus mercantilist views, theory and evidence. Open Economies Review, 18, 191-214.

Aizenman, J., Lee, J., 2008. Financial versus monetary mercantilism: long - run view of large international reserves hoarding. World Economy 31, 593-611.

Aizenman, J., Marion, N., 2003. The high demand for international reserves in the Far East: What is going on? Journal of the Japanese and international Economies 17, 370-400.

Aizenman, J., Glick, R.. 2009. Sovereign wealth funds: Stylized facts about their determinants and governance. International Finance 12.3: 351-386.

Aizenman, J. Y. Jinjarak, D. Park, 2011. International reserves and swap lines: substitutes or complements? International Review of Economics and Finance, (2011), 20, pp. 5-18.

Aizenman, J., Y. Sun., 2012. The financial crisis and sizable international reserves depletion: From 'fear of floating' to the 'fear of losing international reserves'? International Review of Economics \& Finance 24 (2012): 250-269.

Aizenman, J., M. Chinn, H. Ito., 2017. Financial Spillovers and Macroprudential Policies, NBER WP 24105.

Anderson, T.W., Hsiao, C., 1982. Formulation and estimation of dynamic models using panel data. Journal of econometrics 18, 47-82.

Arellano, M. and S. Bond, 1991. Some tests of specification for panel data: Monte Carlo evidence and an application to employment equations. The Review of Economic Studies 58: 27797.

Beck, R., Rahbari, E., 2011. Optimal reserve composition in the presence of sudden stops. Journal of International Money and Finance 30, 1107-1127.

Beck, R and Mehl, A., 2013. "Global safe asset shortage, non-traditional reserve currencies and the global financial crisis”, in The International Role of the Euro, European Central Bank, Frankfurt am Main

Ben-Bassat Avraham, 1984. Reserve-Currency diversification and the substitution account, Princeton Studies in International Finance, No. 53, March 1984.

Bernanke, Ben S. and Bertaut, Carol C. and DeMarco, Laurie and Kamin, Steven B., International Capital Flows and the Return to Safe Assets in the United States, 2003-2007 (April 11, 2011). FRB International Finance Discussion Paper No. 1014.

Bussière, M., Cheng, G., Chinn, M. D., \& Lisack, N., 2015. For a few dollars more: Reserves and growth in times of crises. Journal of International Money and Finance, 52, 127-145.

Caballero, R.J., 2006. On the macroeconomics of asset shortages. National Bureau of Economic Research.

Caballero, R., Farhi, E., 2017. The safety trap. The Review of Economic Studies 85, 223-274. 
Caballero, R.J., Farhi, E., Gourinchas, P.-O., 2017. The safe assets shortage conundrum. Journal of Economic Perspectives 31, 29-46.

Calvo, G. A. 1998. Capital flows and capital-market crises: the simple economics of sudden stops. Journal of applied Economics 1.1 (1998): 35-54.

Chinn, M., Frankel, J.A., 2008. Will the euro eventually surpass the dollar as leading international reserve currency? In: G7 Current account imbalances: sustainability and adjustment. University of Chicago Press, pp. 283-338.

Cheung, Y-W., Ito, H., 2009. A Cross-Country Empirical Analysis of International Reserves. International Economic Journal 23, 447-481.

Cheung, Y-W., Qian, X., 2009. Hoarding of international reserves: Mrs Machlup's wardrobe and the Joneses. Review of International Economics 17, 824-843.

Cheung Y-W., Qian, X., Remolona, E., 2019. The Hoarding of International Reserves: It's a neighborly day in Asia. Pacific Economic Review (24), 208-240.

Cox, D. R. and N. Wermuth, 1992. A comment on the coefficient of determination for binary responses. American Statistician 161: 1-4.

Dominguez, K.M., Hashimoto, Y., Ito, T., 2012. International reserves and the global financial crisis. Journal of International Economics 88, 388-406.

Dooley, M.P., Lizondo, S., Mathieson, D., 1989. The currency composition of foreign exchange reserves. International Monetary Fund Staff Papers 36 (2), 385-434.

Eichengreen, B., Mathieson, D., 2000. The Currency Composition of Foreign Exchange

Reserves: Retrospect and Prospect. IMF Working Paper 131.

Eichengreen, B., Chiţu, L., Mehl, A., 2016. Stability or upheaval? The currency composition of international reserves in the long run. IMF Economic Review 64, 354-380.

Everitt, B. S., 2002. Cambridge Dictionary of Statistics (2nd ed.).

Frenkel, J. A., 1974. The Demand for International Reserves by Developed and Less-Developed Countries, Economica, 141, pp. 14-24.

Frankel, J. A., 2007. Exchange Rate Policy. in American Economic Policy in the 1980s, ed. by Martin Feldstein (Chicago: University of Chicago Press), pp. 293-341.

Goldberg, L. S., C. Hull, and S. K. Stein, 2013. Do industrialized countries hold the right foreign exchange reserves? Current Issues in Economics and Finance 19, no. 1.

Gorton, G. B. and G. Ordonez, 2013. The supply and demand for safe assets, National Bureau of Economic Research.

Gourinchas, Pierre-Olivier and Jeanne, Olivier, 2012. Global Safe Assets. BIS Working Paper No. 399.

Hansen, Lars Peter, 1982. "Large Sample Properties of Generalized Method of Moments Estimators". Econometrica. 50 (4): 1029-1054.

He, Zhiguo, Arvind Krishnamurthy, and Konstantin Milbradt, 2016a. A model of safe asset determination, National Bureau of Economic Research. 
He, Zhiguo, Arvind Krishnamurthy, and Konstantin Milbradt, 2016b. What makes us government bonds safe assets? American Economic Review 106, 519-23.

Heller, H.R., Knight, M.D., 1978. Reserve-currency preferences of central banks. International Finance Section, Dept. of Economics, Princeton University.

Ito, H., McCauley, R.N., Chan, T., 2015. Currency composition of reserves, trade invoicing and currency movements. Emerging Markets Review 25, 16-29.

Jeanne, O., and Rancière, R., 2011. The optimal level of international reserves for emerging market countries: A new formula and some applications. The Economic Journal 121, 905-930.

Krishnamurthy, A., Vissing-Jorgensen, A., 2012. The Aggregate Demand for Treasury Debt. Journal of Political Economy 120, 233-267.

Miranda-Agrippino, Silvia and Helene Rey, 2019. Us Monetary Policy and the Global Financial Cycle (November 2015). NBER Working Paper No. w21722.

Neely, C.J., 2000. Are changes in foreign exchange reserves well correlated with official intervention? Fed. Reserve Bank St. Louis Rev. 82 (5), 17-32.

Obstfeld, M., 1983. Exchange rates, inflation, and the sterilization problem: Germany, 19751981. European Economic Review 21, 161-189.

Obstfeld, M., 1996. Models of currency crises with self-fulfilling features. European Economic Review 40, 1037-1047.

Obstfeld, M., Shambaugh, J.C., Taylor, A.M., 2009. Financial instability, reserves, and central bank swap lines in the panic of 2008. American Economic review 99, 480-86.

Obstfeld, M., Shambaugh, J.C., Taylor, A.M., 2010. Financial stability, the trilemma, and international reserves. American Economic Journal: Macroeconomics 2, 57-94.

Papaioannou, E., Portes, R., Siourounis, G., 2006. Optimal currency shares in international reserves: the impact of the euro and the prospects for the dollar. Journal of the Japanese and International Economies. Elsevier 20 (4), 508-547.

Rey, H., 2015. Dilemma not trilemma: the global financial cycle and monetary policy independence. NBER Working Paper 21162.

Rodrik, D., 2006. The social cost of foreign exchange reserves. International Economic Journal 20, 253-266.

Schneider, Martin, and Aaron Tornell, 2004, Balance sheet effects, bailout guarantees and financial crises, The Review of Economic Studies 71, 883-913.

Steiner, Andreas, Sven Steinkamp, and Frank Westermann. 2019, Exit strategies, capital flight and speculative attacks: Europe's version of the trilemma. European Journal of Political Economy (https://doi.org/10.1016/j.ejpoleco.2019.02.003).

Wong, A., 2007. Measurement and inference in international reserve diversification. Peterson Institute for International Economics Working Paper.

Zheng, B. and A. Agresti, 2000. Summarizing the predictive power of a generalized linear model. Statistics in Medicine 19: 1771-1781. 


\section{Appendix A: variable definitions}

IR in Bigfour: the aggregate share of international reserves in big four currencies, namely US dollar, Euro, Sterling Pounds, and Japanese Yen, in total IR excluding Gold. The data of big four currencies in international reserves are retrieved from IMF's International Reserves and Foreign Currency Liquidity (IMF IRFCL) http://data.imf.org/?sk=2DFB3380-36034D2C-90BE-A04D8BBCE237\&sId=1390030341854. IRFCL publishes the annual data for the amount (in US dollar) of SDR basket currencies (US dollar, Euro, Sterling Pounds, and Japanese Yen; RMB is included in 2016 and 2017) from 1999 to 2017. Due to short periods for the RMB data, we purge them by subtracting countries' holding of RMB as reserve currency in 2016 and 2017. The holding of RMB as IR in 2016 and 2017 are published in IRFCL.

Trade with Bigfour: the ratio of a country's imports and exports of goods with US, Euro area, UK, and JP to its total imports and exports with the world. Source: Direction of Trade

Anchor: $\quad$ the dummy variable for a country that anchor its currency exchange rate to US Dollar. Source: Ilzetzki, Reinhart, and Rogoff (2016); (http://www.carmenreinhart.com/data/browse-by-topic/topics/11/)

Xchg rgm: the dummy variable for exchange rate regime, constructed from the coarse measurement of Ilzetzki, Reinhart, and Rogoff (2016), in which the authors indexed from 1 to 5 for exchange regime according to its flexibility from "NO separate legal tender", "De facto peg" to "freely floating" and "freely falling". The higher the index, the more flexible the exchange regime is.

Gold Share: the ratio of gold reserve assets in total international reserves including gold, IMF IFS. GDP Share: the share of a country's GDP in the World GDP, WDI.

Debt in USDEuro: the share of outstanding international debt security that a country issued in US Dollar and Euro in its total international debt. Source: BIS statistics warehouse (https://stats.bis.org/\#ppq=CBS C AND OTH EXP UR;pv=11 10,5,6 0,0,0 name)

SWAP: $\quad$ a dummy for bilateral swap agreements (SWAP). SWAP $=1$, if a country is in an agreement of bilateral currency swap (regardless of the currency of the agreement) such as the Fed, the ECB, and the Bank of Japan. Otherwise, 0. The data are compiled using website information (Aizenman, Cheung, and Ito, 2015).

SWF: $\quad$ The size of sovereign wealth fund in billion USD, in logarithm value. Source: the SWF Institute (http://www.swfinstitute.org/fund-rankings/).

IR/GDP: the ratio of international reserves excluding gold to GDP. Source: IMF IFS.

Stock Mkt Size: $\quad$ the share of stock trade turnover of US, Euro area, UK, and Japan in the world's total stock trade turnover. Source: WDI

Inflation diff: the GDP share weighted average of inflation difference between US, Euro, UK, and Japan and other OECD countries. Source: WDI

Inertia: lagged dependent variable, the share of currency in USD, Euro, Pound, and Yen in total reserves, to capture the inertial bias in favor of whatever currency is used in the past in reserves (Chinn and Frankel, 2008).

GSA Global safe assets, measured as total consolidated central government debt (Maastricht definition) of Germany, Japan, UK, and US, weighted by world GDP. Source: ECB Statistical Data Warehouse.

GSA_OECD Global safe assets, measured as total OECD central government debt rated AA and above, then weighted by world GDP. Source: ECB Statistical Data Warehouse and WDI.

GSA_YD: Global safe assets measured as the average yield of 10-year government bond of big four (US, Germany, UK, and Japan) and emerging markets (represented by Korea, Mexico, Russia, and South Africa). Source: FRED St. Louis Fed. 
GSA_T2: The alternative GSA measurement for Euro countries where German T2 payment balance is considered as one type of GSAs, which is added to GSAs provided by Germany, Japan, UK, and US government debt.

VIX: $\quad$ Financial fear gauge, the CBOE Volatility Index that measured by market expectation of near-term volatility conveyed by stock index option prices. Source: FRED St. Louis Fed.

ToT: $\quad$ Net barter terms of trade index $(2000=100)$, in logarithm value. A high index indicates the improvement of term of trade. Source: WDI

T2B: $\quad$ The Target 2 payment balance in million Euro, converted into USD using period average spot rate. T2 liability is turned to positive number before regressions, therefore, high T2B indicates high T2 liability. Source: Euro Crisis Monitor http://www.eurocrisismonitor.com/

GFC08 As time dummy variable measures the 2008 global financial crisis (GFC08 $=1$ if year>2008; otherwise, 0)

QE Taper $\quad$ As time dummy variable measures Fed's QE tapering (Taper = 1 if year $>2013$; otherwise, 0)

\section{Appendix B: Country samples}

Advanced economies: Australia, Austria, Belgium, Canada, Cyprus, Denmark, Finland, France, Germany, Greece, Iceland, Ireland, Italy, Luxembourg, Malta, Netherlands, New Zealand, Norway, Portugal, Singapore, Spain, Sweden, Switzerland

Emerging markets and developing economies: Albania, Argentina, Brazil, Bulgaria, Chile, Colombia, Croatia, Czech Republic, Estonia, Hungary, Indonesia, Israel, Jamaica, Kazakhstan, Korea, Latvia, Lithuania, Macedonia, Malaysia, Mauritius, Mexico, Morocco, Peru, Philippines, Poland, Romania, Russian Federation, Slovak Republic, Slovenia, South Africa, Thailand, Tunisia, Turkey, Ukraine, Uruguay

Commodity exporter countries (country exporting fuel and ores and metals more than $25 \%$ of its total merchandise exports): Armenia, Australia, Belarus, Bolivia, Bulgaria, Canada, Chile, Colombia, Egypt, Greece, Iceland, Indonesia, Kazakhstan, Norway, Peru, Russia, South Africa

Euro countries: Austria, Belgium, Cyprus, Estonia, Finland, France, Germany, Greece, Ireland, Italy, Latvia, Lithuania, Luxembourg, Malta, Netherlands, Portugal, Slovakia, Slovenia, Spain

OECD sovereign rated AA or above by S\&P: Australia, Austria, Belgium, Canada, Denmark, Finland, France, Germany, Luxembourg, Netherlands, New Zealand, Norway, Sweden, Switzerland, United Kingdom, United States 
Table 1: the determinants of currency composition in international reserves

\begin{tabular}{cccc}
\hline & All & EMDE & ADV \\
Trade with Bigfour & $0.561^{* * *}$ & $0.539^{* * *}$ & $0.230^{*}$ \\
Anchor & $(0.107)$ & $(0.108)$ & $(0.119)$ \\
& $7.627^{*}$ & $7.585^{* *}$ & 7.109 \\
Xchg_rgm & $(3.950)$ & $(3.226)$ & $(5.911)$ \\
& 1.926 & 0.581 & $3.673^{*}$ \\
Gold Share & $(2.223)$ & $(1.948)$ & $(2.028)$ \\
& 0.036 & $0.101^{*}$ & -0.019 \\
GDP Share & $(0.036)$ & $(0.051)$ & $(0.032)$ \\
& 1.632 & -0.126 & 0.164 \\
SWF & $(2.136)$ & $(2.993)$ & $(0.705)$ \\
& $-4.606^{* *}$ & -2.068 & -0.918 \\
Stock Mkt Size & $(2.063)$ & $(1.576)$ & $(0.622)$ \\
& $0.166^{* * *}$ & $0.193^{* * *}$ & 0.046 \\
Inflation Diff & $(0.030)$ & $(0.030)$ & $(0.027)$ \\
& -0.536 & -0.625 & 0.034 \\
Inertia & $(0.403)$ & $(0.458)$ & $(0.314)$ \\
& $0.225^{* * *}$ & $0.284^{* * *}$ & $0.532^{* * *}$ \\
Constant & $(0.064)$ & $(0.057)$ & $(0.092)$ \\
& $-44.542^{* * *}$ & $-42.249^{* * *}$ & $-22.653^{* *}$ \\
Hansen J stats. & $(7.741)$ & $(6.613)$ & $(9.501)$ \\
AR(1) & & & \\
AR(2) & 52.84 & 48.08 & 22.49 \\
Adj. Pseudo R2 & -3.89 & -4.28 & -2.25 \\
Obs. & -0.89 & -0.84 & -0.73 \\
& 0.240 & 0.315 & 0.259 \\
& 1218 & 828 & 390 \\
\hline
\end{tabular}

Note: this table reports the results of dynamic panel data system GMM with a lagged dependent variable, labeled as "Inertia", as an independent variable. All independent variables are lagged one year. Robust errors are in parentheses. “***”, “**”, and “*” mark for significant at 1\%, 5\%, and $10 \%$, respectively. 
Table 2: the results for the balance sheet insurance effect on the currency composition of IR, all countries sample

\begin{tabular}{ccccc}
\hline & $(1)$ & $(2)$ & $(3)$ & $(4)$ \\
Trade with Bigfour & $0.456^{* * *}$ & $0.441^{* * *}$ & $0.438^{* * *}$ & $0.444^{* * *}$ \\
& $(0.125)$ & $(0.130)$ & $(0.118)$ & $(0.118)$ \\
Anchor & $9.694^{* *}$ & $7.804^{*}$ & $11.062^{* * *}$ & $9.082^{* *}$ \\
& $(3.655)$ & $(4.448)$ & $(3.286)$ & $(3.586)$ \\
Stock Mkt Size & $0.070^{* * *}$ & $0.086^{* * *}$ & $0.048^{*}$ & $0.066^{* * *}$ \\
& $(0.025)$ & $(0.025)$ & $(0.027)$ & $(0.024)$ \\
Inflation Diff & $-0.808^{* *}$ & $-0.999^{* *}$ & $-0.769^{* *}$ & $-0.893^{* *}$ \\
& $(0.376)$ & $(0.394)$ & $(0.348)$ & $(0.363)$ \\
Inertia & $0.375^{* * *}$ & $0.380^{* * *}$ & $0.338^{* * *}$ & $0.372^{* * *}$ \\
& $(0.086)$ & $(0.071)$ & $(0.088)$ & $(0.084)$ \\
Debt in USDEuro & $0.041^{* *}$ & & $0.095^{* * *}$ & $0.042^{* *}$ \\
& $(0.019)$ & & $(0.030)$ & $(0.019)$ \\
SWAP & & -0.909 & -0.189 & 0.594 \\
& & $(0.621)$ & $(0.619)$ & $(0.838)$ \\
Debt in USDEuro*SWAP & & & & $-0.023^{*}$ \\
Constant & $-34.847 * * *$ & $-31.600^{* * *}$ & $-36.072 * * *$ & $-33.393^{* * *}$ \\
& $(8.008)$ & $(8.109)$ & $(7.421)$ & $(7.450)$ \\
Hansen J stats. & 54.68 & & & \\
AR(1) & -3.67 & -45.05 & 51.61 & 53.45 \\
AR(2) & -1.24 & -1.06 & -3.36 & -3.73 \\
Adj. Pseudo R2 & 0.377 & 0.393 & -1.19 & -1.13 \\
Obs. & 845 & 845 & 8.359 & 0.402 \\
\hline
\end{tabular}

Note: this table reports the results of dynamic panel data system GMM with a lagged dependent variable, labeled as "Inertia", as an independent variable. All independent variables are lagged one year. All countries are in data sample. Robust errors are in parentheses. “***”, “**”, and “*” mark for significant at $1 \%, 5 \%$, and $10 \%$, respectively. 
Table 3: the results for the balance sheet insurance effect on the currency composition of IR, EMDE countries sample

\begin{tabular}{|c|c|c|c|c|}
\hline & (1) & $(2)$ & (3) & (4) \\
\hline \multirow[t]{2}{*}{ Trade with Bigfour } & $0.217 * *$ & $0.250 * * *$ & $0.189 * *$ & $0.213 * *$ \\
\hline & $(0.088)$ & $(0.089)$ & $(0.087)$ & $(0.085)$ \\
\hline \multirow[t]{2}{*}{ Xchg_rgm } & 0.450 & 0.203 & $0.656^{*}$ & 0.451 \\
\hline & $(0.295)$ & $(0.310)$ & $(0.325)$ & $(0.295)$ \\
\hline \multirow[t]{2}{*}{ Stock Mkt Size } & $0.115^{* * *}$ & $0.141^{* * *}$ & $0.098 * * *$ & $0.113^{* * *}$ \\
\hline & $(0.032)$ & $(0.032)$ & $(0.033)$ & $(0.032)$ \\
\hline \multirow[t]{2}{*}{ Inflation Diff } & $-0.973 * *$ & $-1.163 * *$ & $-0.909 * *$ & $-0.979 * *$ \\
\hline & $(0.390)$ & $(0.460)$ & $(0.339)$ & $(0.388)$ \\
\hline \multirow[t]{2}{*}{ Inertia } & $0.407 * * *$ & $0.398 * * *$ & $0.381 * * *$ & $0.404^{* * *}$ \\
\hline & $(0.097)$ & $(0.082)$ & $(0.094)$ & $(0.097)$ \\
\hline \multirow[t]{2}{*}{ Debt in USDEuro } & $0.032 * *$ & & $0.063 * * *$ & $0.033 * *$ \\
\hline & $(0.014)$ & & $(0.015)$ & $(0.014)$ \\
\hline \multirow[t]{2}{*}{ SWAP } & & -0.358 & 0.112 & 0.217 \\
\hline & & $(0.904)$ & $(0.809)$ & $(0.767)$ \\
\hline Debt in USDEuro * SWAP & & & & $-0.015 * *$ \\
\hline & & & & $(0.006)$ \\
\hline \multirow[t]{2}{*}{ Constant } & $-20.304 * * *$ & $-21.119 * * *$ & $-20.022 * * *$ & $-19.855 * * *$ \\
\hline & (5.299) & (4.715) & (4.906) & (5.018) \\
\hline Hansen J stats. & 32.39 & 32.51 & 32.79 & 31.69 \\
\hline $\mathrm{AR}(1)$ & -3.86 & -4.12 & -3.75 & -3.83 \\
\hline $\operatorname{AR}(2)$ & -1.52 & -1.26 & -1.53 & -1.55 \\
\hline Adj. pseudo R2 & 0.353 & 0.338 & 0.315 & 0.366 \\
\hline Obs. & 463 & 463 & 463 & 463 \\
\hline
\end{tabular}

Note: this table reports the results of dynamic panel data system GMM with a lagged dependent variable, labeled as "Inertia”, as an independent variable. All independent variables are lagged one year. EMDE countries are in data sample. Robust errors are in parentheses. “***”, “**”, and “*” mark for significant at $1 \%, 5 \%$, and $10 \%$, respectively. 
Table 4: the results for the balance sheet insurance effect on the currency composition of IR, ADV countries sample

\begin{tabular}{|c|c|c|c|c|}
\hline & (1) & $(2)$ & (3) & $(4)$ \\
\hline \multirow[t]{2}{*}{ Gold Share } & $-0.052 * *$ & $-0.033^{*}$ & $-0.038 * *$ & $-0.044 * *$ \\
\hline & $(0.020)$ & $(0.018)$ & $(0.017)$ & $(0.017)$ \\
\hline \multirow[t]{2}{*}{ SWF } & $-0.465 * *$ & -0.320 & $-0.444^{*}$ & $-0.479 *$ \\
\hline & $(0.221)$ & $(0.190)$ & $(0.231)$ & $(0.240)$ \\
\hline \multirow[t]{2}{*}{ Stock Mkt Size } & $0.050 * *$ & 0.027 & 0.017 & $0.031^{*}$ \\
\hline & $(0.021)$ & $(0.016)$ & $(0.013)$ & $(0.016)$ \\
\hline \multirow[t]{2}{*}{ Inertia } & $0.538 * * *$ & $0.590 * * *$ & $0.512 * * *$ & $0.513^{* * *}$ \\
\hline & $(0.078)$ & $(0.039)$ & $(0.077)$ & $(0.080)$ \\
\hline \multirow[t]{2}{*}{ Debt in USDEuro } & $-0.028 *$ & & $-0.030 * *$ & $-0.039 *$ \\
\hline & $(0.015)$ & & $(0.014)$ & $(0.020)$ \\
\hline \multirow[t]{2}{*}{ SWAP } & & $-1.065 *$ & $-1.869 * * *$ & $-1.918 *$ \\
\hline & & $(0.599)$ & $(0.657)$ & $(1.021)$ \\
\hline \multirow[t]{2}{*}{ Debt in USDEuro * SWAP } & & & & 0.013 \\
\hline & & & & $(0.011)$ \\
\hline \multirow[t]{2}{*}{ Constant } & 0.472 & 0.375 & $3.925 * * *$ & $3.094 * *$ \\
\hline & (1.511) & (1.074) & $(1.178)$ & $(1.426)$ \\
\hline Hansen J stats. & 21.09 & 22.04 & 20.35 & 20.01 \\
\hline $\mathrm{AR}(1)$ & -1.99 & -2.36 & -1.95 & -1.95 \\
\hline $\operatorname{AR}(2)$ & -0.81 & -0.13 & -0.13 & -0.12 \\
\hline Adj. pseudo R2 & 0.546 & 0.585 & 0.532 & 0.521 \\
\hline Obs. & 382 & 382 & 382 & 382 \\
\hline
\end{tabular}

Note: this table reports the results of dynamic panel data system GMM with a lagged dependent variable, labeled as “Inertia”, as an independent variable. All independent variables are lagged one year. ADV countries are in data sample. Robust errors are in parentheses. “***”, “**”, and “*” mark for significant at $1 \%, 5 \%$, and $10 \%$, respectively. 
Table 5: the results for the currency composition of IR with the balance sheet insurance effect, scale effect and the effect of GSA, EMDE countries sample

\begin{tabular}{cccc}
\hline & $(1)$ & $(2)$ & $(3)$ \\
Trade with Bigfour & $0.118^{* *}$ & $0.209^{* *}$ & $0.113^{* *}$ \\
Xchg_rgm & $(0.053)$ & $(0.083)$ & $(0.045)$ \\
& $1.136^{*}$ & 0.394 & $0.533^{*}$ \\
Stock Mkt Size & $(0.639)$ & $(0.277)$ & $(0.308)$ \\
& 0.045 & $0.103^{* * *}$ & 0.032 \\
Inflation Diff & $(0.032)$ & $(0.030)$ & $(0.029)$ \\
& $-0.623^{* *}$ & $-1.246^{* * *}$ & $-0.738^{* *}$ \\
Inertia & $(0.272)$ & $(0.404)$ & $(0.289)$ \\
& $0.411^{* * *}$ & $0.382^{* * *}$ & $0.408^{* * *}$ \\
Debt in USDEuro & $(0.077)$ & $(0.098)$ & $(0.076)$ \\
& $0.028^{* *}$ & $0.030^{* *}$ & $0.025^{* *}$ \\
SWAP & $(0.013)$ & $(0.013)$ & $(0.011)$ \\
& 0.368 & 0.841 & 0.853 \\
Debt in USDEuro*SWAP & $(0.570)$ & $(0.871)$ & $(0.685)$ \\
& $-0.015^{* *}$ & $-0.018^{* * *}$ & $-0.015^{*}$ \\
IR/GDP & $(0.008)$ & $(0.006)$ & $(0.008)$ \\
& $-0.092^{* *}$ & & $-0.087 * *$ \\
GSA & $(0.044)$ & & $(0.041)$ \\
& & $-0.184^{* * *}$ & $-0.115^{* *}$ \\
Constant & & $(0.069)$ & $(0.051)$ \\
& $-9.445^{* *}$ & $-10.308^{*}$ & -1.673 \\
Hansen J stats. & $(4.072)$ & $(5.396)$ & $(3.835)$ \\
AR(1) & & & 26.32 \\
AR(2) & 28.15 & 26.63 & -3.89 \\
Adj. pseudo R2 & -3.81 & -3.76 & -1.38 \\
Obs. & -1.43 & -1.54 & 0.495 \\
& 0.474 & 0.469 & 463 \\
\hline
\end{tabular}

Note: this table reports the results of dynamic panel data system GMM with a lagged dependent variable, labeled as "Inertia", as an independent variable. Independent variables are lagged one year and the inclusion of independent variables is based on Table 3 as the standard. EMDE countries are in data sample. Robust errors are in parentheses. “***”, “**”, and “*” mark for significant at $1 \%, 5 \%$, and $10 \%$, respectively. 
Table 6: the results for the currency composition of IR with the balance sheet insurance effect, scale effect and alternative measurements for GSA, EMDE countries sample

\begin{tabular}{|c|c|c|c|}
\hline \multirow{3}{*}{ Trade with Bigfour } & (1) & (2) & (3) \\
\hline & $0.114 * * *$ & $0.090 * *$ & $0.098 * *$ \\
\hline & $(0.044)$ & $(0.042)$ & $(0.041)$ \\
\hline \multirow{2}{*}{ Xchg_rgm } & 0.507 & 0.290 & 0.354 \\
\hline & $(0.314)$ & $(0.294)$ & $(0.314)$ \\
\hline \multirow[t]{2}{*}{ Stock Mkt Size } & 0.010 & $0.061^{* *}$ & $0.097 * * *$ \\
\hline & $(0.028)$ & $(0.029)$ & $(0.032)$ \\
\hline \multirow[t]{2}{*}{ Inflation Diff } & $-0.846 * * *$ & $-0.625 *$ & $-1.997 * * *$ \\
\hline & $(0.327)$ & $(0.334)$ & $(0.660)$ \\
\hline \multirow[t]{2}{*}{ Inertia } & $0.427 * * *$ & $0.431^{* * *}$ & $0.433 * * *$ \\
\hline & $(0.076)$ & $(0.079)$ & $(0.071)$ \\
\hline \multirow{2}{*}{ Debt in USDEuro } & $0.025 * *$ & $0.025^{* *}$ & $0.022 * *$ \\
\hline & $(0.012)$ & $(0.012)$ & $(0.011)$ \\
\hline \multirow[t]{2}{*}{ SWAP } & 0.351 & -0.335 & 0.138 \\
\hline & (1.166) & (1.094) & $(1.060)$ \\
\hline \multirow[t]{2}{*}{ Debt in USDEuro*SWAP } & -0.006 & -0.016 & -0.005 \\
\hline & $(0.018)$ & $(0.016)$ & $(0.016)$ \\
\hline \multirow[t]{2}{*}{ IR/GDP } & $-0.091 * *$ & $-0.090 * *$ & $-0.107 * * *$ \\
\hline & $(0.040)$ & $(0.041)$ & $(0.037)$ \\
\hline \multirow[t]{2}{*}{ GSA_OECD } & $-0.276 * *$ & & \\
\hline & $(0.111)$ & & \\
\hline \multirow[t]{2}{*}{ GSA_YD } & & $0.250^{* *}$ & \\
\hline & & $(0.119)$ & \\
\hline \multirow[t]{2}{*}{ GSA } & & & $-0.599 * * *$ \\
\hline & & & $(0.224)$ \\
\hline \multirow[t]{2}{*}{ VIX } & & & $-0.989 * *$ \\
\hline & & & $(0.387)$ \\
\hline \multirow[t]{2}{*}{ GSA *VIX } & & & $0.021 * *$ \\
\hline & & & $(0.009)$ \\
\hline \multirow[t]{2}{*}{ Constant } & 2.832 & $-8.464 * *$ & $18.041^{* *}$ \\
\hline & $(4.951)$ & (3.489) & (9.163) \\
\hline Hansen J Stats. & 23.48 & 29.32 & 26.89 \\
\hline AR(1) & -3.93 & -3.90 & -4.00 \\
\hline $\mathrm{AR}(2)$ & -1.35 & -1.37 & -1.40 \\
\hline Adj. pseudo R2 & 0.491 & 0.539 & 0.509 \\
\hline Obs. & 463 & 463 & 463 \\
\hline
\end{tabular}

Note: this table reports the results of dynamic panel data system GMM with a lagged dependent variable, labeled as "Inertia", as an independent variable. Independent variables are lagged one year and the inclusion of independent variables is based on in Table 3 as the standard. EMDE countries are in data sample. Robust errors are in parentheses. “***”, “**”, and “*” mark for significant at $1 \%, 5 \%$, and $10 \%$, respectively. 
Table 7: the results for the effect of 2008 global financial crisis and the Fed's QE taper to the currency composition of IR

\begin{tabular}{|c|c|c|c|}
\hline & EMDE & & ADV \\
\hline Trade with Bigfour & $\begin{array}{l}0.087^{* *} \\
(0.039)\end{array}$ & Gold Share & $\begin{array}{l}-0.040^{*} \\
(0.021)\end{array}$ \\
\hline Trade with Bigfour*GFC08 & $\begin{array}{c}-0.080 * * \\
(0.038)\end{array}$ & Gold Share*GFC08 & $\begin{array}{l}0.036^{*} \\
(0.021)\end{array}$ \\
\hline GDP Share & $\begin{array}{c}-2.256 \\
(1.824)\end{array}$ & SWF & $\begin{array}{c}0.049 \\
(0.087)\end{array}$ \\
\hline GDP Share*GFC08 & $\begin{array}{l}5.109 * \\
(2.679)\end{array}$ & & \\
\hline Xchg_rgm & $\begin{array}{l}2.161^{* * *} \\
(1.074)\end{array}$ & & \\
\hline Stock Mkt Size & $\begin{array}{c}0.015 \\
(0.037)\end{array}$ & Stock Mkt Size & $\begin{array}{c}0.060 * * \\
(0.028)\end{array}$ \\
\hline Inflation Diff & $\begin{array}{c}-1.085^{* *} \\
(0.552)\end{array}$ & & \\
\hline Inertia & $\begin{array}{c}0.207 * * \\
(0.084)\end{array}$ & Inertia & $\begin{array}{c}0.523^{* * *} \\
(0.061)\end{array}$ \\
\hline Debt in USDEuro & $\begin{array}{l}0.037^{*} \\
(0.021)\end{array}$ & Debt in USDEuro & $\begin{array}{c}0.014 \\
(0.017)\end{array}$ \\
\hline SWAP & $\begin{array}{l}-0.220 \\
(1.381)\end{array}$ & SWAP & $\begin{array}{c}1.765 \\
(1.569)\end{array}$ \\
\hline Debt in USDEuro * SWAP & $\begin{array}{c}0.000 \\
(0.019)\end{array}$ & Debt in USDEuro * SWAP & $\begin{array}{l}-0.020 \\
(0.019)\end{array}$ \\
\hline GFC08 & $\begin{array}{c}-5.101 * * * \\
(1.793)\end{array}$ & GFC08 & $\begin{array}{c}-2.060 * * \\
(1.044)\end{array}$ \\
\hline IR/GDP & $\begin{array}{c}-0.161^{* *} \\
(0.074)\end{array}$ & & \\
\hline IR/GDP * GFC08 & $\begin{array}{l}0.195 * * \\
(0.096)\end{array}$ & & \\
\hline QE Taper & $\begin{array}{l}25.511^{*} \\
(14.308)\end{array}$ & QE Taper & $\begin{array}{c}16.167 * * \\
(7.490)\end{array}$ \\
\hline GSA & $\begin{array}{c}0.032 \\
(0.120)\end{array}$ & GSA & $\begin{array}{c}0.037 \\
(0.041)\end{array}$ \\
\hline QE Taper*GSA & $\begin{array}{c}-0.529 * \\
(0.292)\end{array}$ & QE Taper*GSA & $\begin{array}{c}-0.330 * * \\
(0.154)\end{array}$ \\
\hline Constant & $\begin{array}{c}-5.477 \\
(6.992)\end{array}$ & Constant & $\begin{array}{c}-5.254 \\
(3.469)\end{array}$ \\
\hline Hansen J stats. & 22.29 & Hansen J test & 16.25 \\
\hline $\mathrm{AR}(1)$ & -3.45 & $\mathrm{AR}(1)$ & -2.08 \\
\hline $\mathrm{AR}(2)$ & -0.98 & $\mathrm{AR}(2)$ & -0.97 \\
\hline Adj. pseudo R2 & 0.490 & Pseudo R2 & 0.703 \\
\hline Obs. & 435 & Obs. & 382 \\
\hline
\end{tabular}

Note: this table reports the results of dynamic panel data system GMM with a lagged dependent variable, labeled as "Inertia”, as an independent variable. All independent variables are lagged one year. Robust errors are in parentheses. “***”, “**”, and “*” mark for significant at 1\%, 5\%, and $10 \%$, respectively. 
Table 8: the results for the currency composition of IR, Euro countries sample

\begin{tabular}{|c|c|c|c|c|c|}
\hline \multirow{3}{*}{ Trade with Bigfour } & $(1)$ & (2) & (3) & (4) & (5) \\
\hline & $0.058^{*}$ & $0.081^{* *}$ & $0.068^{* *}$ & $0.071^{* *}$ & $0.079 * *$ \\
\hline & $(0.030)$ & $(0.034)$ & $(0.028)$ & $(0.031)$ & $(0.031)$ \\
\hline \multirow[t]{2}{*}{ SWF } & -0.244 & $-1.005^{* * *}$ & -0.733 & $-0.906 * * *$ & $-1.043 * *$ \\
\hline & $(0.417)$ & $(0.362)$ & $(0.494)$ & $(0.317)$ & $(0.527)$ \\
\hline \multirow[t]{2}{*}{ Inertia } & $0.373 * * *$ & $0.384 * * *$ & $0.380 * * *$ & $0.381 * * *$ & $0.387 * * *$ \\
\hline & $(0.085)$ & $(0.114)$ & $(0.090)$ & $(0.116)$ & $(0.116)$ \\
\hline \multirow[t]{2}{*}{ Debt in USD } & -0.002 & $0.023 *$ & 0.007 & 0.017 & $0.024 *$ \\
\hline & $(0.014)$ & $(0.012)$ & $(0.014)$ & $(0.013)$ & $(0.014)$ \\
\hline \multirow[t]{2}{*}{ IR/GDP } & $0.158^{* * *}$ & $0.113 * *$ & $0.150^{* * *}$ & $0.122 * *$ & $0.113 * *$ \\
\hline & $(0.047)$ & $(0.045)$ & $(0.048)$ & $(0.049)$ & $(0.044)$ \\
\hline \multirow[t]{2}{*}{ GSA } & $-0.131 * *$ & $-0.059 *$ & & $-0.080 * * *$ & -0.048 \\
\hline & $(0.062)$ & $(0.034)$ & & $(0.030)$ & $(0.035)$ \\
\hline \multirow[t]{2}{*}{ T2B/GDP } & & $1.769 * * *$ & & & $1.755^{* * *}$ \\
\hline & & $(0.555)$ & & & $(0.427)$ \\
\hline GSA_T2 & & & $\begin{array}{c}-0.128^{* *} \\
(0.058)\end{array}$ & & \\
\hline T2B_threshold & & & & $\begin{array}{c}2.808 \\
(2.483)\end{array}$ & \\
\hline Euro Crisis 5 & & & & & $\begin{array}{c}0.547 \\
(0.859)\end{array}$ \\
\hline Euro Crisis $5 * \mathrm{~T} 2 \mathrm{~B} / \mathrm{GDP}$ & & & & & $\begin{array}{l}-2.052 \\
(2.558)\end{array}$ \\
\hline Constant & $\begin{array}{c}2.513 \\
(3.698)\end{array}$ & $\begin{array}{c}-2.513 \\
(2.700)\end{array}$ & $\begin{array}{c}1.618 \\
(3.425)\end{array}$ & $\begin{array}{c}-0.921 \\
(2.226)\end{array}$ & $\begin{array}{l}-2.984 \\
(2.672)\end{array}$ \\
\hline Hansen J stats. & 10.75 & 8.05 & 11.06 & 8.07 & 6.28 \\
\hline $\mathrm{AR}(1)$ & -2.01 & -1.94 & -2.02 & -1.96 & -1.94 \\
\hline $\mathrm{AR}(2)$ & -0.13 & -1.55 & -0.28 & -1.80 & -1.55 \\
\hline Adj. pseudo R2 & 0.709 & 0.693 & 0.719 & 0.669 & 0.676 \\
\hline Obs. & 283 & 233 & 249 & 233 & 233 \\
\hline
\end{tabular}

Note: this table reports the results of dynamic panel data system GMM with a lagged dependent variable, labeled as "Inertia”, as an independent variable. Column (1) reports results with 18 Euro countries, excluding Germany; Column (2) adds TARGET2 liabilities as an independent variable; Column (3) reports when Germany's TARGET2 balance is treated as alternative GSA. Column (4) add TARGET2 liabilities that are exceeding 1 s.d. threshold as an independent variable. Column (5) singles out five Euro crisis inflicted countries. Germany is also excluded from regression samples in Column (2), (3), (4), and (5) as well. All independent variables are lagged one year. Robust errors are in parentheses. “***”, “**”, and “*” mark for significant at $1 \%, 5 \%$, and $10 \%$, respectively. 
Table 9: the results for the currency composition of IR, commodity exporter countries sample

\begin{tabular}{cccc}
\hline & $(1)$ & $(2)$ & $(3)$ \\
Stock Mkt Size & $0.063^{* *}$ & $0.153^{* * *}$ & $0.055^{* *}$ \\
Inflation Diff & $(0.028)$ & $(0.047)$ & $(0.027)$ \\
& 0.007 & $-1.199^{*}$ & -0.140 \\
Inertia & $(0.379)$ & $(0.681)$ & $(0.362)$ \\
& $0.509^{* * *}$ & $0.518^{* * *}$ & $0.498^{* * *}$ \\
IR/GDP & $(0.037)$ & $(0.127)$ & $(0.041)$ \\
& $-1.555^{* *}$ & & $-1.338^{*}$ \\
IR/GDP * ToT & $(0.788)$ & & $(0.719)$ \\
& $0.321^{* *}$ & & $0.275^{*}$ \\
ToT & $(0.163)$ & & $-10.149)$ \\
& $-8.043^{* *}$ & $-5.234^{*}$ & $(2.812)$ \\
GSA & $(3.261)$ & $(2.763)$ & -0.064 \\
& & $-0.135 * *$ & $(0.042)$ \\
Constant & & $(0.060)$ & $34.595^{* *}$ \\
& $35.878^{* *}$ & 21.304 & $(14.360)$ \\
Hansen J stats. & $(15.759)$ & $(14.843)$ & 8.77 \\
AR(1) & 12.51 & & -2.98 \\
AR(2) & -2.96 & 14.02 & -0.86 \\
Adj. pseudo R2 & -0.78 & -2.72 & 0.626 \\
Obs. & 0.622 & -1.27 & 288 \\
\hline
\end{tabular}

Note: this table reports the results of dynamic panel data system GMM with a lagged dependent variable, labeled as "Inertia", as an independent variable. All independent variables are lagged one year. Robust errors are in parentheses. “***”, “**”, and “*” mark for significant at $1 \%, 5 \%$, and $10 \%$, respectively. 
Table 10: the results for the currency composition of IR after taking consider in the valuation effect from Euro/US dollar exchange rate changes

\begin{tabular}{|c|c|c|c|}
\hline Trade with Bigfour & $\begin{array}{c}\text { EMDE } \\
0.014^{* * *} \\
(0.003)\end{array}$ & Gold Share & $\begin{array}{c}\text { ADV } \\
0.002 \\
(0.002)\end{array}$ \\
\hline Trade with Bigfour*GFC08 & $\begin{array}{c}-0.019 * * * \\
(0.003)\end{array}$ & Gold Share*GFC08 & $\begin{array}{c}-0.005^{*} \\
(0.003)\end{array}$ \\
\hline GDP Share & $\begin{array}{c}-0.760 * * \\
(0.315)\end{array}$ & SWF & $\begin{array}{c}-0.021 \\
(0.013)\end{array}$ \\
\hline GDP Share*GFC08 & $\begin{array}{c}0.847 * * * \\
(0.323)\end{array}$ & & \\
\hline Xchg_rgm & $\begin{array}{l}0.193^{* *} \\
(0.087)\end{array}$ & & \\
\hline Stock Mkt Size & $\begin{array}{c}0.001 \\
(0.002)\end{array}$ & Stock Mkt Size & $\begin{array}{c}0.005^{* * *} \\
(0.001)\end{array}$ \\
\hline Inflation Diff & $\begin{array}{l}0.059 * \\
(0.032)\end{array}$ & & \\
\hline Inertia & $\begin{array}{c}0.153^{* * *} \\
(0.016)\end{array}$ & Inertia & $\begin{array}{c}0.169 * * * \\
(0.005)\end{array}$ \\
\hline Debt in USDEuro & $\begin{array}{c}0.000 \\
(0.002)\end{array}$ & Debt in USDEuro & $\begin{array}{l}-0.004 \\
(0.002)\end{array}$ \\
\hline SWAP & $\begin{array}{c}0.074 \\
(0.086)\end{array}$ & SWAP & $\begin{array}{c}-0.840 * * * \\
(0.308)\end{array}$ \\
\hline Debt in USDEuro * SWAP & $\begin{array}{l}-0.000 \\
(0.001)\end{array}$ & Debt in USDEuro * SWAP & $\begin{array}{l}0.006^{*} \\
(0.003)\end{array}$ \\
\hline GFC08 & $\begin{array}{l}-0.059 \\
(0.146)\end{array}$ & GFC08 & $\begin{array}{c}0.225 \\
(0.171)\end{array}$ \\
\hline IR/GDP & $\begin{array}{c}-0.005 \\
(0.004)\end{array}$ & & \\
\hline IR/GDP * GFC08 & $\begin{array}{c}0.003 \\
(0.008)\end{array}$ & & \\
\hline QE Taper & $\begin{array}{c}6.726 * * * \\
(0.889)\end{array}$ & QE Taper & $\begin{array}{c}5.255^{* * * *} \\
(0.219)\end{array}$ \\
\hline GSA & $\begin{array}{c}0.036 * * * \\
(0.006)\end{array}$ & GSA & $\begin{array}{c}0.004^{* *} \\
(0.001)\end{array}$ \\
\hline QE Taper*GSA & $\begin{array}{c}-0.138^{* * * *} \\
(0.019)\end{array}$ & QE Taper*GSA & $\begin{array}{c}-0.107^{* * *} \\
(0.005)\end{array}$ \\
\hline Constant & $\begin{array}{l}-0.288 \\
(0.402)\end{array}$ & Constant & $\begin{array}{c}1.655^{* * *} * \\
(0.162)\end{array}$ \\
\hline Hansen J stats. & 28.06 & Hansen J test & 22.98 \\
\hline $\mathrm{AR}(1)$ & -2.57 & $\mathrm{AR}(1)$ & -3.02 \\
\hline $\mathrm{AR}(2)$ & -0.29 & $\mathrm{AR}(2)$ & -0.38 \\
\hline Adj. pseudo R2 & 0.562 & Pseudo R2 & 0.731 \\
\hline Obs. & 407 & Obs. & 339 \\
\hline
\end{tabular}

Note: this table reports the results of dynamic panel data system GMM with a lagged dependent variable, labeled as "Inertia”, as an independent variable. All independent variables are lagged one year. Robust errors are in parentheses. “***”, “**”, and “*” mark for significant at 1\%, 5\%, and $10 \%$, respectively. 
Figure 1: The global share of big four versus other reserves currencies

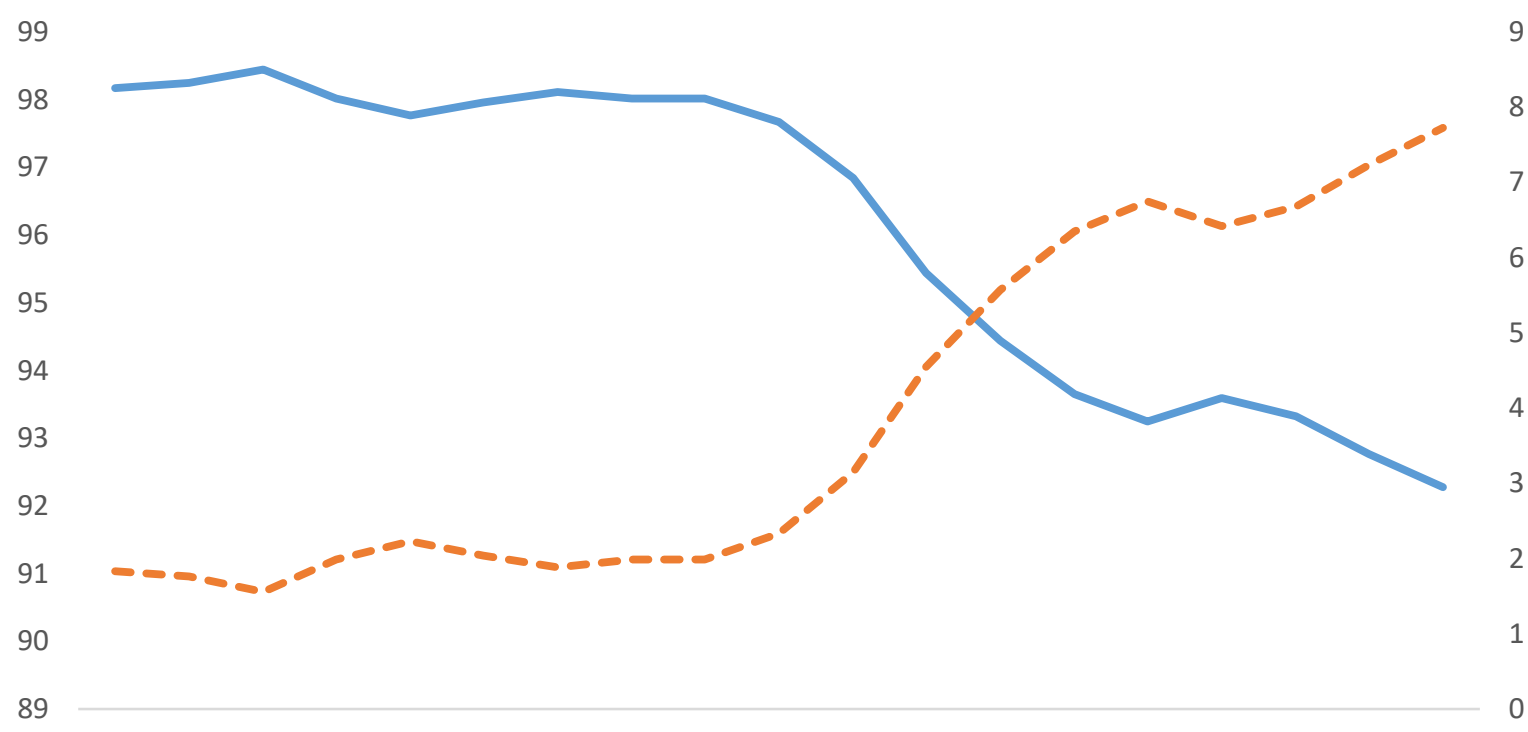

1999200020012002200320042005200620072008200920102011201220132014201520162017 Share of bigfour $\quad$ - Share of other reserve currencies

Data source: IMF COFER data

Figure 2: The average share of holding of big four currencies in IR: EMDE v.s. ADV

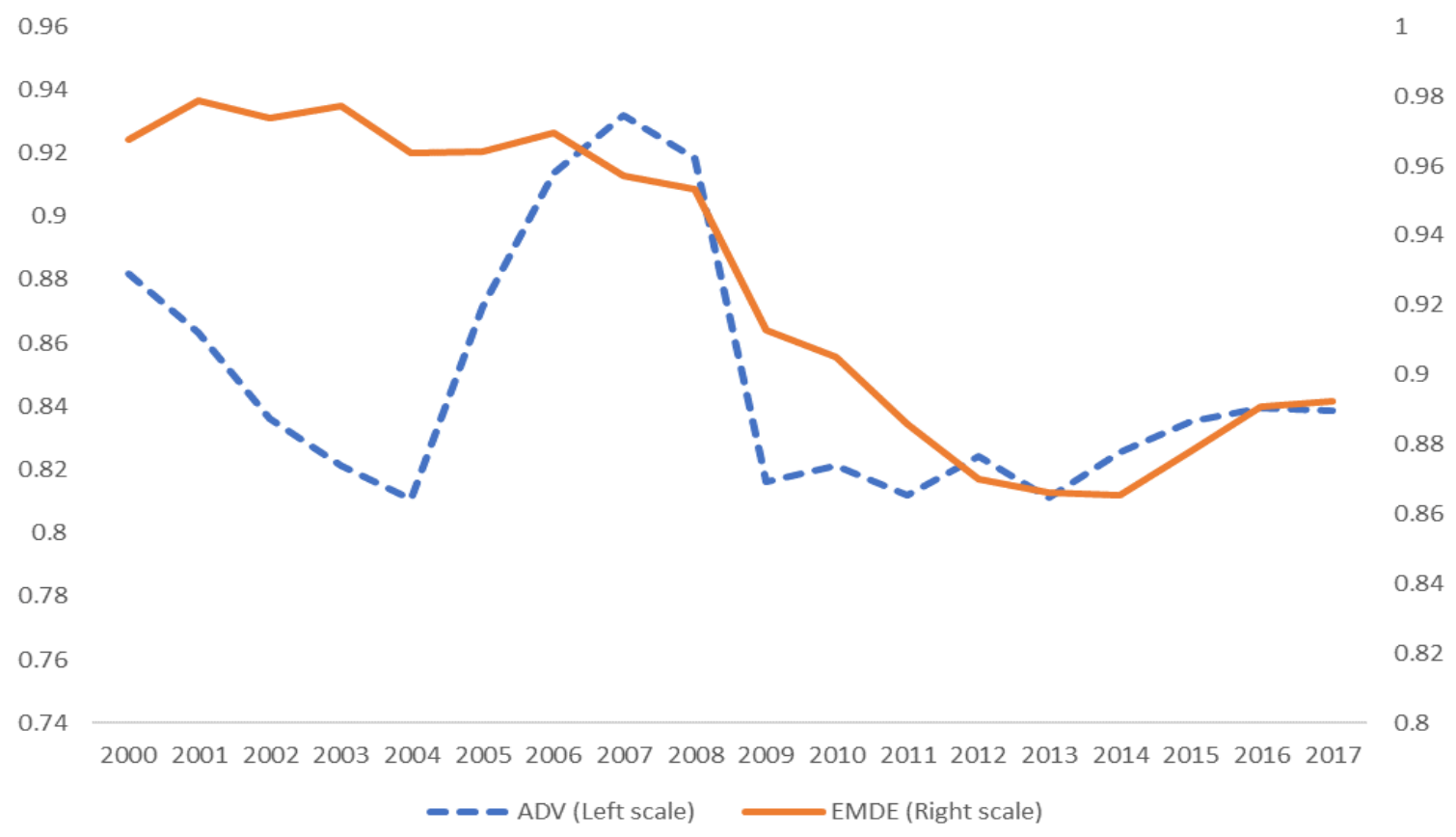

Data source: IMF IRFCL and IMF IFS 
Figure 3: The aggregate share of holding of big four currencies in IR: EMDE v.s. ADV

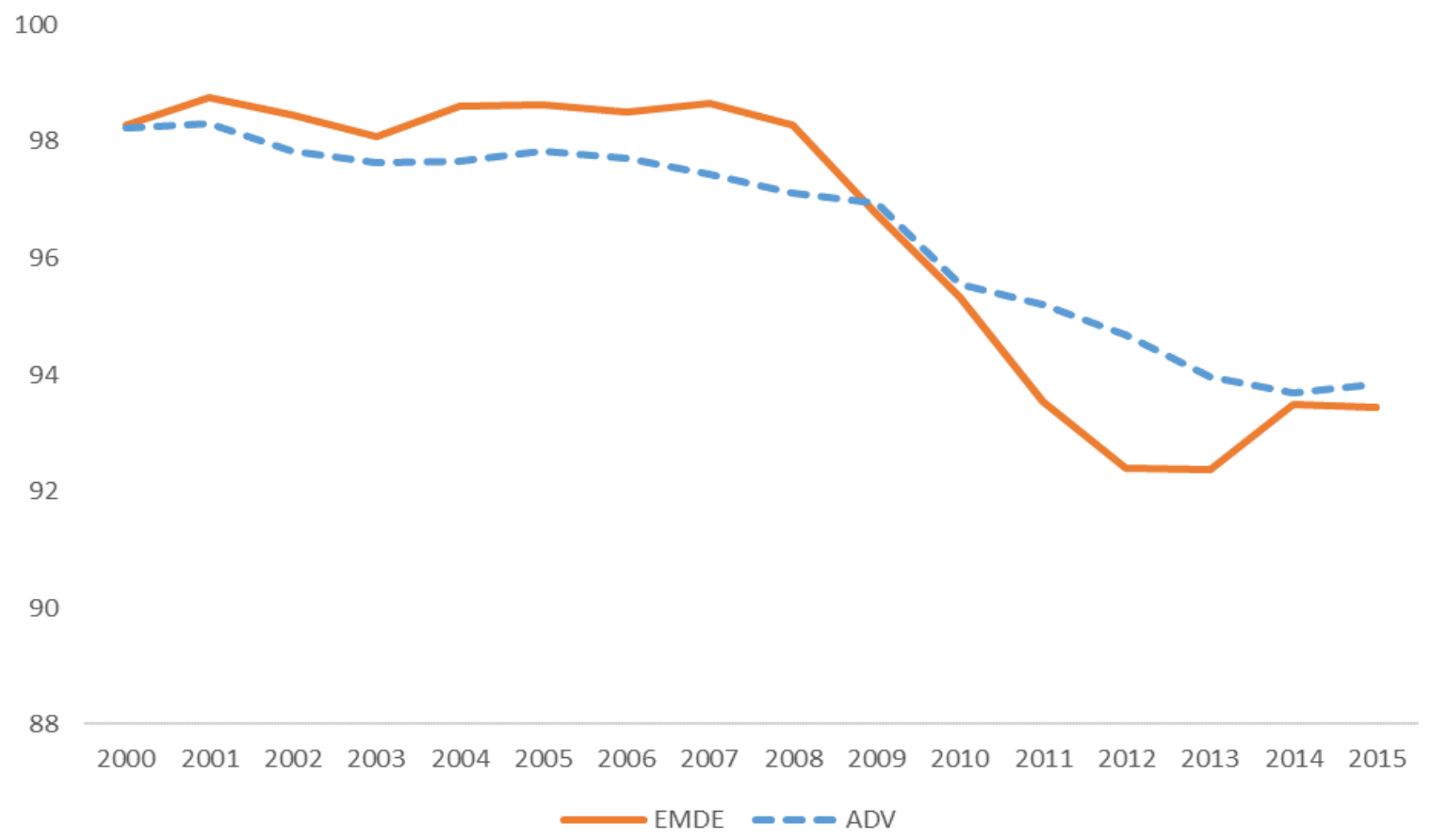

Data source: IMF COFER

Figure 4: The global share of US\$ and Euro and the Euro/US\$ exchange rate

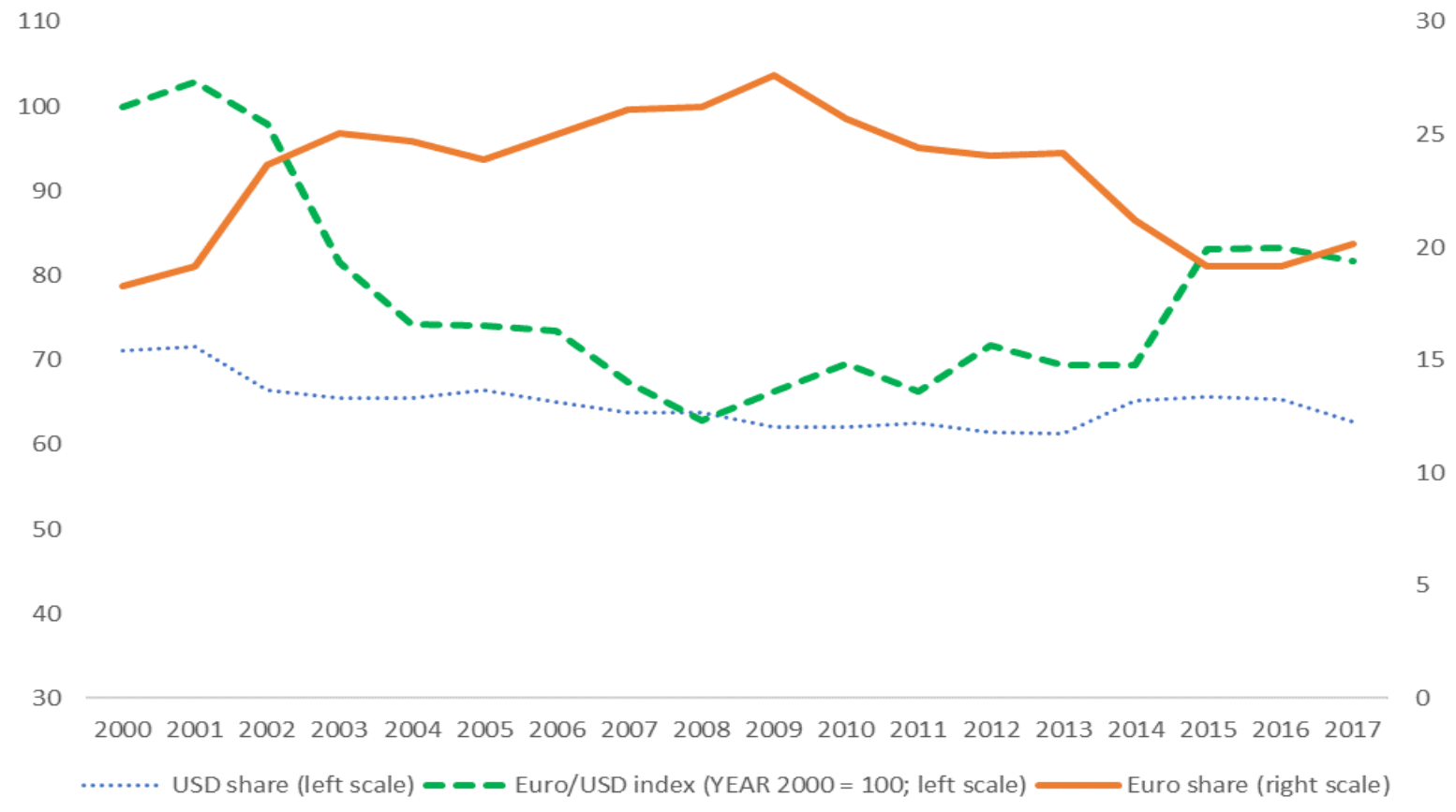

Data source: IMF COFER and IFS 